HUMAN TRAFFICKING: A CONTEMPORARY PERSPECTIVE

By

Aidan Kerr, BA, Ryerson University, 2018

\author{
A Major Research Paper \\ presented to Ryerson University \\ In partial fulfillment of the requirements for the degree of \\ Master of Arts \\ in the program of \\ Immigration and Settlement Studies
}

Toronto, Ontario, Canada, 2018

CAidan Kerr, 2018 


\section{AUTHOR’S DECLARATION FOR ELECTRONIC SUBMISSION OF A MAJOR RESEARCH PAPER}

\section{(MRP)}

I hereby declare that I am the sole author of this MRP. This is a true copy of the MRP, including any required final revisions. I authorize Ryerson University to lend this MRP to other institutions or individuals for the purpose of scholarly research. I further authorize Ryerson University to reproduce this MRP by photocopying or by other means, in total or in part, at the request of other institutions or individuals for the purpose of scholarly research. I understand that my MRP may be made electronically available to the public. 


\title{
HUMAN TRAFFICKING: A CONTEMPORARY PERSPECTIVE
}

\author{
Aidan Kerr \\ Master of Arts, 2018 \\ Immigration and Settlement Studies \\ Ryerson University
}

\begin{abstract}
$\underline{\text { Abstract }}$
The goal of this Major Research Paper is to demonstrate the global totality of modern slavery by explaining its connection with human trafficking, and to provide a robust understanding of the topic for further meaningful research. Human trafficking is a form of slavery and is used to supply the slave industry with victims from all over the world. As with slavery, the trafficking of humans has ancient roots and continues to thrive today. From the ancient Code of Hammurabi, which denotes the laws of the slave, to the covert nature of slavery today, slavery and the trade of humans shows no signs of slowing.
\end{abstract}

Key Words: Modern Slavery; Human Trafficking; Organized Crime; Border Security; Immigration 


\section{$\underline{\text { Acknowledgements }}$}

I would like to thank my dear friend and supervisor, Professor Dr. Arne Kislenko, for his unwavering support during the creation of this MRP. A special thanks to Sarah Prince for editing my work. You volunteered your time and effort without obligation and provided thoughtful insight. To Sarah Eskandarpour, thank you for constantly pushing me to do my best. To my parents, Carolyn and Kyle, thank you for everything that you have done for me. To my brothers, Rory, Naveed and Daniel, thank you for the laughs and keeping my ego in check. Thank you all for your love and support. 
Table of Contents

Author's Declaration

Abstract

iii

Acknowledgements

iv

Introduction

Historical Context

The Cold War Era

Criminal Organizations

The Palermo Protocols

Contemporary Statistics

Perspectives on Combating Trafficking and Modern Slavery

Conclusion

References 


\section{Introduction}

Slavery is alive and well. In 2016, the International Labour Office (ILO) reported that approximately 40 million people are enslaved today. ${ }^{1}$ The ILO also stated that in tandem with those enslaved, over 20 million people are considered victims of trafficking. ${ }^{2}$ The mass manufacturing and service provision demanded by the global economy and its competitive nature have inadvertently created a clandestine world of production where slavery plays an essential role. As competition is the cornerstone of the neoliberal global economy, the implications and consequences of this underground world of production are often hidden. Many of the products that we use on a daily basis can be connected to production facilities, both foreign and domestic, infamous for abhorrent work conditions and gross violations of human rights. In 2017, the United Kingdom's civil society coalition on corporate accountability (CORE) highlighted materials like cocoa from West Africa, mica from India, and mined gold for jewellery all as raw materials that are routinely part of the forced labour underground economy. CORE found that cocoa from West Africa was used by several prominent chocolate corporations like, Ferrero, Hershey, Lindt, and Mars. ${ }^{3}$ These corporations all have made statements regarding plans to use 100\% sustainable cocoa from West Africa by 2020 but while Mars acknowledged severe human rights issues within the industry, Hershey, Lindt and Ferrero made no mention of supply chains or source countries. ${ }^{4}$ With regard to mined gold, CORE found that companies like Tiffany \& Co

\footnotetext{
1 "Global estimates of modern slavery: Forced labour and forced marriage, International Labour Office (ILO)," United Nations, Geneva, 2017, date accessed: August $1^{\text {st }}$, 2018, https://www.ilo.org/global/publications/books/WCMS 575479/lang--en/index.htm.

2 "Human Trafficking: More than 20 million victims," European Parliament, last modified October 18, 2016, date accessed: June $25^{\text {th }} 2018$, http://www.europarl.europa.eu/news/en/headlines/world/20161014STO47261/humantrafficking-more-than-20-million-victims-worldwide

3 "Risk Averse? Company reporting on raw material and sector-specific risks under the Transparency in Supply Chains clause in the UK Modern Slavery Act 2015.” CORE. (2017). 14-19. http://corporatejustice.org/171003_riskaverse-final-1.pdf

${ }^{4}$ Ibid, 14.
} 
and Cartier did very little to publicly address the fact that the gold mining industry is wrought with human rights violations and forced child labour. ${ }^{5}$ The global food industry and agricultural industries are also plagued by slavery. A large portion of the 2.5 billion pounds of seafood that are imported into the United States per year come from South East Asia where the fisheries are largely staffed by child labourers who work in extremely dangerous conditions. ${ }^{6}$

This lack of acknowledgement and action is no secret, but several factors influence the modern consumer. Although many consumers have been made aware of the nefarious origins of the products that stock the shelves of retail and grocery stores, they continue to buy as low prices are, in some cases, irresistible. In recent history, the notion of modern slave labour came as a shock to consumers, sparking free trade movements in the 1960s, 1970s, and 1980s. Such movements have held in some industries. The Free Trade coffee industry, although flawed, is an example of the potential for a shift in production. Large catastrophic events also draw attention to these issues. Canadian consumers were shocked when, on April 24 $4^{\text {th }}, 2013,1130$ workers were killed in the collapse of the factory where they produced clothing for Loblaws affiliate brand, Joe Fresh. ${ }^{7}$ The company saw nationwide condemnation, and for a short time, the Canadian consumer was aware of the slave-like conditions associated with the production of fast fashion. Unfortunately, this consciousness fades quickly. It is difficult to avoid the low prices offered by companies that utilize the poor working conditions overseas. The capitalist system that dominates the global economy demands a competitive labour force which can create jobs and

\footnotetext{
${ }^{5}$ Ibid, 21.

${ }^{6}$ Kevin Bales, Blood and Earth: Modern Slavery, Ecocide, and the Secret to Saving the World. First ed. Spiegel \& Grau, 2016, 75.

${ }^{7}$ Hilary Beaumont, “Three Years After a Factory Collapse Killed 1,130 Workers, This Brand is Still Making Clothes in Bangladesh," Vice News, April 22, 2016, date accessed: March 20 ${ }^{\text {th }}, 2018$. https://news.vice.com/article/three-years-after-a-factory-collapse-killed-1130-workers-this-brand-is-still-makingclothes-in-bangladesh.
} 
keep prices low, but it also forces manufacturers to produce goods at extremely low costs, often harming work conditions. Although it is not always difficult to uncover unethical practices in corporate supply chains, the true element that keeps slavery alive today is its clandestine nature.

Thought primarily to be a problem of impoverished countries and born of corruption and a lack of education, modern slavery is generally dismissed from mainstream discussion despite sometimes making news. As defined by the international organization Anti-Slavery, modern slavery is a state of "being exploited and completely controlled by someone else, without being able to leave." ${ }^{8}$ Anti-Slavery lists the modern forms of slavery: forced labour, debt bondage, human trafficking, descent-based slavery, child slavery and forced/early marriage. ${ }^{9}$ Each of these forms is incredibly complex. Drawing attention to the atrocities of slavery that persist today is paramount in ending the trade and trafficking of humans. The waning meaning attributed to the term "slavery", bastardized in today's colloquial speech, serves as a testament to a lack of understanding of modern slavery. Slavery is not solely a problem of distant countries and ancient history. The troubling fact is that slavery is woven deep into modern societal institutions. Corruption and compliance cripple international attempts at combatting human trafficking. Governments refuse to take up arms against criminal organizations operating within state borders, allowing for the slavery to persist. Although the international community has developed a robust framework for the policing and prevention of human trafficking and slavery, combatting these crimes requires the effort of individual states, and this is often seriously lacking

The goal of this Major Research Paper is to demonstrate the global totality of modern slavery by explaining its connection with human trafficking, and to provide a robust

\footnotetext{
8 "What is modern slavery?" anti-slavery, Last modified, 2018, date accessed: July $15^{\text {th }}, 2018$. https://www.antislavery.org/slavery-today/modern-slavery/.

${ }^{9}$ Ibid.
} 
understanding of the topic for further meaningful research. Human trafficking is a form of slavery and is used to supply the slave industry with victims from all over the world. As with slavery, the trafficking of humans has ancient roots and continues to thrive today. From the ancient Code of Hammurabi, which denotes the laws of the slave, to the covert nature of slavery today, slavery and the trade of humans shows no signs of slowing.

The research methods employed in this MRP highlight the strengths of studying human trafficking and slavery and mitigate the weaknesses. There is a relatively deep expanse of literature about trafficking and modern slavery. Gaining a firm grasp of the general argument and the state of contemporary research is attainable in this field. The main issue with studying trafficking and slavery stems from a lack of empirical data and the difficulty in engaging in primary research. In "A Formidable Task: Reflections on Obtaining Legal Empirical Evidence on Human Trafficking in Canada," Millar, O'Dobery, and Roots address the fact that much of the research concerning Canadian trafficking is not based on empirical data. This is due to the Canadian legal system's short history with trafficking laws. Over the last decade, Canada has made several attempts to bolster its anti-trafficking laws, with substantial changes to the criminal code taking place on June $6^{\text {th }}$, 2012 with the introduction of the National Action Plan to Combat Human Trafficking. ${ }^{10}$ Although a positive step in the fight against trafficking, because of the relative infancy of these laws, Canada has a very low conviction rate. Millar et al note that the subject of human trafficking is highly politicized in Canada, making it impossible to access documents regarding the efficiency of the country's anti-trafficking laws. ${ }^{11}$ For this reason, this

\footnotetext{
10 "The Harper Government Launches Canada's National Action Plan to Combat Human Trafficking," Public Safety Canada, Last modified, June $6^{\text {th }}, 2012$, date accessed: June $25^{\text {th }}, 2018$, https://web.archive.org/web/20130703001948/https://www.publicsafety.gc.ca/media/nr/2012/nr20120606-eng.aspx. ${ }^{11}$ Hayli Millar, Tamara O'Doherty, and Katrin Roots, "A Formidable Task: Reflections on Obtaining Legal Empirical Evidence on Human Trafficking in Canada," Anti-Trafficking Review no. 8 (2017), 2.
} 
MRP will take a wider approach to the study of human trafficking. Reference will be made to cases related to Canada when applicable, but this review will also draw from the global nature of human trafficking, and explore the limitations in policing which are rooted in the lack of empirical evidence. Although it is possible to build on empirical data through field research, research of this nature in any field relating to criminal activity is dangerous and the safety of the researcher must be considered. ${ }^{12}$ Conducting ethical interviews with survivors or offenders requires considerable time and training. Victims of forced labour experience vastly difference abuses than those of sex slavery or trafficking for domestic servitude. Age demographics further complicate research, as does the internationality of traffickers and trafficking victims. In the article, "Human Trafficking and Migration Management in the Global South", Stephanie Nawyn, Nur Banu Kavakli, Tub Demirci-Tilmaz, and Vanja Pantic Oflazoglu discuss the benefits, and shortcomings, of the broad definition of trafficking. Because the legal definition of trafficking encompasses different forms of exploitation, the pool of perpetrators and victims vary by a large margin. This makes studying trafficking, policing traffickers, and servicing victims extremely complex. As stated by Nawyn et al, the care required by a minor coerced into sexual labour is vastly different than that of an adult male who travels to a new country with the promise of work only to be forced to work without pay. ${ }^{13}$ This concept can be taken further when considering the internationality of victims and the varying cultural norms, languages, and customs and how these elements influence the services required to rehabilitate a victim.

Due to the scope of this MRP, primary research methods involving in-depth field research cannot be applied. In order to contribute meaningfully to the academic discussion on

\footnotetext{
12 Brian L. Withrow, Research Methods in Crime and Justice (London: Routledge, 2013) 61.

${ }^{13}$ Stephanie J. Nawyn, Nur Banu Kavakli, Tuba Demirci-Yılmaz, and Vanja Pantic Oflazoğlu. "Human Trafficking and Migration Management in the Global South," International Journal of Sociology 46, No. 3 (2016): 192.
} 
human trafficking and modern slavery, an integrative review has been applied as it leverages existing research attained by professionals in the field. An integrative research review will uncover themes, intersections, and differences in the approaches to ending human trafficking and slavery. The review will be organized into Harris Cooper's Five-Step Conceptualization as discussed by Cynthia L. Russell. Cooper's conceptualization begins with problem formulation. The problem, in this case, is addressing the causes and potential solutions to modern slavery and human trafficking. The next step is data collection or literature search followed by an evaluation and then analysis of the data collected. Research was conducted prior to beginning this MRP and continued during the writing process. The final step in Cooper's conceptualization is interpretation and presentation of results which takes form in this completed MRP. ${ }^{14}$

This discussion will begin with an account of the history of slavery and trafficking, discussing its origins and comparable modern manifestations. This will be followed by an examination of the causality of trafficking. This examination will demonstrate the global nature of trafficking, moving to specific examples of regions and criminal organizations most notable for trafficking today. Next will be a review of the modern legal definitions of organized crime, human trafficking, and human smuggling created by the United Nations (UN) and the protocols surrounding human trafficking that were born of historical anti-slavery movements. The final section will explore options for eliminating trafficking on the national scale. Although many authors offer good arguments for the cause of trafficking, very few explore tangible methods to combat it at the international level. The deeply rooted complexities stemming from the international nature of trafficking make service provision and rehabilitation extremely difficult.

\footnotetext{
${ }^{14}$ Cynthia L. Russell, "An Overview of the Integrative Research Review," Progress in Transplantation 15, no. 1 (2005): 8 .
} 
The global nature of trafficking coupled with the disconnected and loose organizational structure of these international criminal organizations makes research and policing and rehabilitation for victims very difficult.

Essential to any discussion regarding the causes and origins of modern trafficking is an exploration of the history that surrounds the institution of slavery and the trafficking of people. Slavery has ancient roots. Since the dawn of recorded human history, the transport, sale and bondage of slaves have persisted. The nature and extent of this trafficking and slavery have shifted over the centuries but historians and anti-slavery experts have identified several common pillars that have marked slavery over time and still exist today. Though slavery has wavered, it as never truly ended.

\section{Historical Context}

In exploring the history of slavery, Bales, Trodd and Williamson assert that wars of expansion brought about by the Byzantine Empire between 320 AD and 1453 AD resulted in a constant flow of slaves into the major cities throughout the Empire. ${ }^{15}$ This increase in slaves, coupled with an agricultural surplus and a ruling elite class, established the pillars of organized or trade slavery. These pillars include a military force capable of enslaving prisoners of war, an economy for the trade of slaves, and a religious elite capable of justifying subjugation with divine rite. ${ }^{16}$ All of these pillars persist today. For example, military forces roaming war-torn lands preying on the desperate have been a mainstay throughout human history.

\footnotetext{
${ }^{15}$ Kevin Bales, Zoe Trodd and Alex Kent Williamson, Modern Slavery: A beginners Guide, (Oxford: Oneworld Publications, 2009) Kindle Edition, Chap. 1.

${ }^{16}$ Ibid.
} 
The military of the ancient Sumerians took enslaved prisoners, selling them as they roamed the plains of Sumer. The Babylonian Code of Hammurabi (circa 1790 BCE) detailed 282 laws and was the first legal document to discuss the role of slaves in society. ${ }^{17}$ Of the laws discussed in the code, 35 dealt directly with the rights of the slave and slave holder. ${ }^{18}$ The ancient Sumerians were not drastically different from modern military groups operating in Central Africa. In the Congo, militia groups frequently raid villages and enslave their inhabitants. Men and boys are forced into labour or the military, while women are forced into sexual slavery. ${ }^{19}$ The pillars presented by Bales et al. represent persistent commonalities, demonstrating that slavery is still thriving today.

Historian Brook Newman identifies three commonalties that further this point. The first commonality is the commodification of people. In this context, the commodification of people refers to converting people into a commodity that can be bought, transferred, and sold. ${ }^{20}$ This commodification is dehumanizing, and its victims can be uprooted at any time. They are never able to settle, cannot own property, and are usually without rights. The commodification of people was achieved through the implementation of laws that stripped people of any rights granted in the legal system at the time. Instead, the rights attached to the slave were afforded to the slave owner, rendering the slave's treatment absolute under the law. This notion connects to the presence of an economy for the state of slaves discussed by Bales et al. The commodification of humans works to rationalize their trafficking and sale.

\footnotetext{
${ }^{17}$ Daniel C. Snell "Slavery in the Ancient Near East" in The Cambridge World History of Slavery. Volume 1: The Ancient Mediterranean World, ed. Elizabeth Meyer, (The Classical Journal 180, no. 2, 2012): 10.

${ }^{18}$ Kevin Bales et al, Modern Slavery: A beginners Guide, Chap 1.

${ }^{19}$ Sarah Fraser, "Human Trafficking in the Democratic Republic of Congo," Borgen Magazine. November 21, 2017, date accessed: June $20^{\text {th }}, 2018$, http://www.borgenmagazine.com/human-trafficking-democratic-republic-congo/. ${ }^{20}$ Brook E. Newman, "Historical Perspective: Slavery Over the Centuries," in Human Trafficking: Interdisciplinary Perspectives, ed. Mary C. Burke, (New York: Routledge, 2013): 27.
} 
The next commonality that transcends time and space is the tendency for slave populations to be 'outsiders'. Newman argues that in most societies, slaves were members of outsider populations. The term outsider, in this case, refers to foreigners, criminals, and ethnically or religiously separate peoples. This is due to the fact that it is easier for a general public to dehumanize foreigners. The use of terminology plays a large role in the dehumanization of foreign people. As Newman explains, "The word slave comes from Slav, a term used to describe people sold into slavery to the Muslims of southern Spain and North Africa during the Middle Ages who originated in the Slavic regions of eastern Europe." ${ }^{21}$ The term Slav had a resurgence in the 1930s, as Adolf Hitler and the Nazis discounted the humanity of millions of Europeans who fit the ethnic specifications associated with the term. Terminology has a profound impact on how groups are treated within society. This is a fact relevant in many discussions today, including the use of the term "refugee" in modern migration discourse.

The third commonality discussed by Newman is the hereditary nature of slavery. Both historically and in modern cases, the children of those bound to slavery inherit their status, a cycle that is traditionally impossible to break. This concept connects to the pillar of religion as a means of rationalization. For slaves in the Roman Empire, emancipation was made legally possible as laws surrounding slaves slackened. The caste system that traditionally denoted class based on a Hindu hierarchy in India made class and enslavement absolute. This permanent slave status based on religion can also be seen in the Christian story of the decedents of Ham. ${ }^{22}$ Noah's son, Ham, was cursed to slavery forever. The European slavers used this concept when colonizing Asia and Africa, creating a narrative that cast indigenous populations of these

\footnotetext{
${ }^{21}$ Ibid, 28.

${ }^{22}$ Kevin Bales et al, Modern Slavery: A beginners Guide, Chap 1.
} 
continents as the descendants of Ham, and as slaves by Christian teaching. ${ }^{23}$ The connection of slavery to lineage and ethnicity works to cripple the ambitions of the slave, further dehumanizing them. Despite these dehumanizing techniques, resistance has been constant throughout the history of slavery. It is in this resistance and the subsequent movements wrought by revolt that modern anti-slavery and anti-trafficking movements developed.

The most prominent early example of large-scale slave resistance is the famous War of Spartacus (73-71 BC) in Ancient Rome. For the duration of the Roman Empire, slavery was the dominant means of large-scale production and development. ${ }^{24}$ This wholesale reliance on slavery would be the basis of the institution of slavery in later centuries. Between 73 to $71 \mathrm{BCE}$, Spartacus led approximately 120,000 freed slaves into combat against the Roman Empire. These slaves were able to attain victory and maintain the resistance over several skirmishes before they were defeated by the Roman army. ${ }^{25}$ Following this revolt, the Roman Empire developed more progressive laws regarding slaves. Soon the understanding of slavery as oppositional to natural law had gained traction in the Empire. ${ }^{26}$ Slavery persisted through the ages, and was present in every major civilization.

In the $15^{\text {th }}$ century, slavery intensified. Upon colonizing Africa and the Americas, the European empires began to enslave the indigenous populations. Between 1640 and 1807 over 8 million slaves were taken from Africa alone. By the mid-1800s, towards the end of the global

\footnotetext{
23 Ibid.

${ }^{24}$ Ronaldo Munck, "Slavery: Exception of Rule?" in Human Trafficking in Europe, ed. Gillian Wylie and Penelope McRedmond, (Basingstoke: Palgrave Macmillan, 2010), 18.

${ }^{25}$ R. Scott Smith \& Christopher Francese. Ancient Rome: An Anthology of Sources. (Indianapolis: Hackett Publishing Company, 2014): 11-13.

${ }^{26}$ Kevin Bales et al, Modern Slavery: A beginners Guide, Chap 1.
} 
slave trade, estimates suggest that 40-100 million slaves were traded. ${ }^{27}$ This period, commonly referred to as the "Atlantic Slave Trade" or "triangular trade", was the largest forced migration in human history and is a clear example of trafficking for forced labour. ${ }^{28}$ These slaves were sent to work in the "new world", with one in every three ships destined for the British Caribbean. ${ }^{29}$ By the late 1600s and early 1700s, the sugar industry in Jamaica, driven by forced labour on plantations, was creating a mercantile class in British society that was wealthier than some members of the gentry. ${ }^{30}$ This wealth brought about power and influence, solidifying the institution of slavery. It is estimated that by 1800 one-third of European trade was dedicated to the legal trade in slaves. ${ }^{31}$ It was not until 1780 that slavery, in the eye of the general British public, started to lose favour.

This shift in public opinion was driven in part by the American Revolution. Many of the British settlers in Jamaica sympathised with the American cause when taxation in the colonies was on the rise. The American Revolution shook the foundations of British colonial holdings. ${ }^{32}$ The abolitionist movement was gaining traction as the British public opposed colonial holdings, and in 1787 the Society of Effecting Abolition of the Slave Trade was created. ${ }^{33}$ The rise of the abolitionist movement and the American Revolution also coincided with the French Revolution and the massively successful Haitian slave revolt. Together, these events resulted in the abolition

\footnotetext{
${ }^{27}$ Munck, "Slavery: Exception of Rule?" 18.

${ }^{28}$ Ibid.

${ }^{29}$ Christer Petley, "Slaveholders and revolution: the Jamaican planter class, British imperial politics, and the ending of the slave trade, 1775-1807," Slavery \& Abolition 39. No. 1 (2017): 55.

${ }^{30}$ Ibid.

${ }^{31}$ Munck, "Slavery: Exception of Rule?" 18.

${ }^{32}$ Petley, "Slaveholders and revolution: the Jamaican planter class, British imperial politics, and the ending of the slave trade, 1775-1807," 57.

${ }^{33}$ Ibid, 60.
} 
of slavery in the British colonies in 1807. Slavery as an institution was abolished in Great Britain completely in $18333^{34}$

In the United States, the import of slaves ended in 1808. The use of slave labour, however, still continued. Used for production on large-scale plantations in the south and for domestic labour in homes across America, slavery was a strong and profitable institution in America. Motivated by the success of the Haitian slave revolt and the abolition of slavery in Great Britain, slaves in the United States held several revolts in the mid $19^{\text {th }}$ century. As antislavery discourse began, civil war was brewing in the United States, throwing the country into turmoil. The abolition of slavery was a lesser issue in the eyes of the American public, who were fixated on the conflict between the Union and the Confederacy. The connection of abolitionism and the Union proved to greatly benefit the abolitionists, and in 1863 the Emancipation Proclamation was signed.

While the latter half of the $19^{\text {th }}$ century saw the abolition of the global slave trade, new forms of exploitation were on the rise. The infamous 'scramble for Africa' saw the continent already rife with death and destruction, divvied up amongst the colonial powers. The British, French, Portuguese, Spanish, Italians, Germans, Belgians, and Dutch all claimed territories in hopes of colonial exploitation. Despite the end of the global slave trade, the destruction associated with the continuation of colonialism perpetuated the core values of slave labour.

The anti-slavery discourse that was moulded by this history not only saw the creation of international laws surrounding slavery, but of human trafficking as well. Human trafficking is by no means a new concept. While human trafficking was implemented by historical slavery

\footnotetext{
${ }^{34}$ Ibid, 66.
} 
through the apprehension, harbouring, and transportation of slaves, the legal term has origins in the mid- $19^{\text {th }}$ century. Cases of human trafficking that fit the modern definition of the crime date back to the end of the $19^{\text {th }}$ century when prominent feminist Josephine Butler discussed white women forced into sexual slavery, using the term, "White Slave Trade." 35 Butler was using this term to describe the transnational movement of white women for use in the global sex industry. White slavery existed in Western Europe, the United States, and South America between the 1880s and 1930s. ${ }^{36}$ Concerns with modern trafficking tend to focus on the defence of women and children living in poorer countries in Eastern Europe, Asia, and Africa. Traditionally, however, these discussions focused on white women being abducted and sold into sex industries catering to men in South America, Africa, and Asia. ${ }^{37}$ Primarily the victims were Jewish women and the traffickers were members of Jewish organized crime groups. As with trafficking victims today, these women were tricked or coerced by violent means to travel domestically and across international borders for sexual exploitation. Traffickers at this time also leveraged connections with corrupted government officials and law enforcement, as is prevalent today. ${ }^{38}$ As sex work was heavily stigmatized, even when victims were able to escape, they would not be welcomed back into their communities. ${ }^{39}$

White slavery was a precursor to modern slavery and trafficking. The condemnation of the 'White Slave Trade' was born of news media and the film industry. Historians argue the

\footnotetext{
${ }^{35}$ Elzbieta M. Gozdziak, and Elizabeth A. Collett, "Research on Human Trafficking in North America: A Review of Literature," International Migration 43, no. 1-2 (2005): 100.

${ }^{36}$ Louise I. Shelley, Human Trafficking: A Global Perspective (Cambridge: Cambridge University Press, 2010): 295.

${ }^{37}$ Jo Doezema, "Loose Women Or Lost Women? the Re-Emergence of the Myth of White Slavery in Contemporary Discourses of Trafficking in Women." Gender Issues 18, no. 1 (1999): 24

${ }^{38}$ Shelley, Human Trafficking: A Global Perspective, 296.

${ }^{39}$ Doezema, "Loose Women Or Lost Women? the Re-Emergence of the Myth of White Slavery in Contemporary Discourses of Trafficking in Women," 24.
} 
scale at which white women were trafficked was vastly exaggerated at the time, ${ }^{40}$ an issue likely linked to its presence in media. Its popularity in media garnered international reaction leading to international agreements and national laws regarding the harbouring and trafficking of white women for prostitution. ${ }^{41}$ The philosophical concepts surrounding human rights born of the slave revolts, anti-slavery and anti-white slavery movements of the $18^{\text {th }}$ and $19^{\text {th }}$ centuries are present in the global discussion on the causes and potential methods of ending slavery today. When discussing the causes of human trafficking it is important to note the link between modern slavery and human trafficking. This link has been thoroughly explored by trafficking and slavery experts, Louise Shelley and Kevin Bales. The poorer populations of the world make up the vast majority of people trafficked each year. This fact is directly connected to the desperation and poverty present in these populations. Lack of employment opportunity, poverty, corruption, waning borders, gender and ethnic discrimination, and political conflict all act as "push" factors for those who end up as victims of human trafficking. Demand for labourers, higher standards of living, and the façade of better lives abroad act as pull factors. ${ }^{42}$

On the surface, it may seem that the abolition of slavery and anti-slavery laws have largely eradicated the traditional practice of slavery. But modern slavery has changed drastically from its traditional counterpart. The majority of international laws today struggle to prevent modern slavery as it is an evolving and nuanced crime. While the legal ownership of humans has been internationally outlawed, modern slavery does not revolve around 'owning' people in the historical sense. Slavery today is about having absolute control over a person to the point that the

\footnotetext{
${ }^{40}$ Ibid, 25.

${ }^{41}$ Ibid, 25.

${ }^{42}$ Shelley, Human Trafficking: A Global Perspective, 37.
} 
humanity of the slave is lost. ${ }^{43}$ The modern slave does not exist in law, and so slaveholders are not held to any standard. As Kevin Bales argues in his aptly titled book Disposable People, modern slaves are completely disposable. The slaves of the $18^{\text {th }}$ and $19^{\text {th }}$ century were relatively expensive. Owning a slave came with rules and laws and the slave was considered to be a longterm investment. ${ }^{44}$ Slavery in the $18^{\text {th }}$ and $19^{\text {th }}$ century was by no means less violent or cruel, but legal ownership came with some form of legal accountability. As slavery is forbidden by international law, the modern slave trade is covert, with no rules or laws governing the trade. As Bales puts it, "Slaveholders have all the benefits of ownership without the legalities." 45 This covert nature results in unchecked abuse where slaves are treated like tools easily tossed aside and replaced when they break down. ${ }^{46}$ While all forms of slavery are terrible and dehumanizing, modern slavery maintains the cruelty and benefits the slaveholder. When in 1808 the importation of slaves was outlawed in the United States, slavery became less common, increasing in value. Modern slavery is fed by an efficient trafficking infrastructure that keeps the supply of slaves constant. Slaves today are in abundance and can always be replaced.

As in Ancient Rome, slavery today fuels many elements of the world economy. The abolishment of slavery was considered to be a climax in the fight for equality and human rights when it should have represented a beginning. Slavery took on new forms and became increasingly clandestine. After the initial abolishment of slavery in Great Britain in 1807, the anti-slavery movement lost its way. ${ }^{47}$ The 'scramble for Africa' and the development of both new and long-standing colonial holdings saw an increase in outsourced labour. The colonial

\footnotetext{
${ }^{43}$ Kevin Bales, Disposable People: New Slavery in the Global Economy, (University of California Press, 1999): 4.

${ }^{44}$ Ibid.

${ }^{45}$ Ibid, 5.

${ }^{46}$ Ibid.

${ }^{47}$ Munck, "Slavery: Exception of Rule?" 18.
} 
powers of Europe in the $20^{\text {th }}$ century increasingly relied on the colonies. The turmoil and violence that marked the $20^{\text {th }}$ century saw the displacement of millions. Those displaced after the Second World War sought refuge in struggling nations all over Europe and Asia.

With the earth's population increasing faster than ever before and many nations plagued by economic strife, the tightening of borders and the reservation of resources became paramount. Populations across countries in Asia, the Middle East, and Africa saw massive increases in population after the Second World War. Many of these countries never saw a complete eradication of slavery. ${ }^{48}$ After the global chaos caused by the First and Second World Wars, colonial holdings finally began to slip, and governments were overhauled as territories vied for independence.

Political and economic instability in many Asian, African, Eastern European, and Arab counties caused governments to become overwhelmed. These governments failed to provide basic services to their populations, creating extreme poverty and populations vulnerable to exploitation. At the same time, the increasing prevalence of the global economy saw an increase in wealth in North America and Western Europe. There was also a sudden increase in wealth amongst small ruling class populations in poorer countries. ${ }^{49}$ The traditional small-scale, selfsufficient farming communities in countries like China, India, and Bangladesh were suddenly transformed into large-scale production farms, bolstering the stark class divide. The land was privatized and the agricultural workers on the newly privatized properties were enslaved. ${ }^{50}$ The amalgamation of rapid population growth, mass poverty, failing governments, globalisation, and regional conflict culminated in the Cold War.

\footnotetext{
${ }^{48}$ Kevin Bales, Disposable People: New Slavery in the Global Economy, 12.

${ }^{49}$ Ibid, 13.

${ }^{50}$ Ibid.
} 


\section{The Cold War Era}

Struggling governments were met with a choice between emulating the democracy of the West, and its rapid industrialization and production, or siding with the Soviet Union and communism. During the Cold War, workers' rights, human rights, and the right to organize and protest were weakened in communist countries during the struggle between democracy and communism. ${ }^{51}$ In the democratic nations of North America and Western Europe, economic freedom and the privatization of the economy were placed at the forefront of society. Once the Cold War ended and the Soviet Union fell, there was an immediate crisis as governmental structures all over South America, Africa, Eastern Europe, and the Middle East became unhinged as revolutionaries that had previously been backed by either the Soviets or the United States, attempted to gain control, often resulting in regimes focused on wealth and power rather than democracy and human rights. Conflict was especially present the Democratic Republic of Congo (the DRC) where a tumultuous political climate following the withdrawal of the Dutch resulted in revolution. Both the United States and the Soviet Union interfered in the revolution, crippling political development and leaving the country in disarray. Today, as a failed state, the DRC stands as a prime example of a country crippled by the Trans-Atlantic Slave Trade, colonialism, resource extraction and then the Cold War. Problems have continued for the DRC as warring factions vie for control, enslaving men, women and children to participate in combat and forced labour carrying on the legacy of unregulated resource extraction.

The relationship between neoliberalism, globalisation, and states that continue to struggle after the Cold War has been crippling to working populations. Countries that struggled following

\footnotetext{
${ }^{51}$ Ibid.
} 
the World Wars and Cold War were restructured under a neoliberal model to facilitate the globalisation process. ${ }^{52}$ This was done primarily through the introduction of structural adjustment programs (SAPs) and export processing zones (EPZs). While deregulation in the movement of capital made some countries wealthier, it relegated populations in other countries to systemic poverty. This poverty drives civil unrest in these regions, forcing the displacement of millions of people. This results in a vicious cycle whereby wealthy states abuse the poorer states, displacing populations and turning profits while simultaneously barring the displaced persons from entry into the benefits of deregulation. While globalisation seeks to relax restrictions on capital moving across the globe and neoliberalism demands a reduced government presence in the market, the state still heavily regulates the global movement of people. This means that while the wealthy state can extract profits in capital from poorer states with very little regulation, people from that region cannot move as freely. This unequal economic development fuels trafficking. As argued by Shelley, the unequal economic development between Latin America and North America has today resulted in illegal crossings between the Mexican and American borders. ${ }^{53}$ The same can be seen in South East Asia where women from Laos, Myanmar, and Cambodia are trafficked into the Thai sex industry. ${ }^{54}$ Demand for slavery and trafficking can be tracked along the same lines as the global economy. The supply and demand theory is fitting in understanding the growth of trafficking. Looking specifically at political instability and conflict, examples in the failed states of Libya, The Congo, and South Sudan are prevalent and act as push and pull factors for trafficking. Hundreds of African refugees are

\footnotetext{
52 Tariq Amin-Khan, "Security and its impact on migrants and refugees," In Immigrant Experiences in North America: Understanding Settlement and Integration, ed. Harald Bauder and John Shields, 118-142, (Toronto: Canadian Scholars' Press, 2015): 121.

${ }^{53}$ Shelley, Human Trafficking: A Global Perspective, 46.

${ }^{54}$ Ibid.
} 
abducted or coerced into entering Libya as slaves to be bought and sold at auction all over the country. In the absence of a legitimate government, traffickers are free to use Libya as a selling ground for slaves. Libya is in a strategic geographical position as it acts as a launch pad into Europe, and functions as a gateway used by some 150,000 irregular migrants per year since 2014. ${ }^{55}$ In the Democratic Republic of the Congo, men and boys are frequently trafficked into slave labour concentrated on resource extraction within the country. Trafficking into the fishing industry and child soldering is also prevalent in these regions. ${ }^{56}$ The women and girls are sent to the sex industry that covers the entire African continent ${ }^{57}$ and that, as exemplified in Libya, has international ties. Those who stay in Africa are often trafficked into brothels that are set up in areas where soldiers are present.

This is even true of international soldiers in countries on peacekeeping missions and has become somewhat of a phenomenon, adding to the international scope of trafficking. The Yugoslav Wars of the 1990s saw South Eastern Europe in disarray. Millions were displaced during the conflict and, as always, traffickers preyed on those displaced. The most troubling element of trafficking in the Yugoslav War example in the demand for trafficking created by the presence of NATO and UN peacekeeping soldiers. Over the course of the conflict, peacekeeping soldiers were deployed. In her report, "Barracks and Brothels, Peacekeepers and Human Trafficking in the Balkans" Sarah E. Mendelson found that between January 2000 and June 2003, some 5203 women had been trafficked into the Balkans. ${ }^{58}$ It is estimated that this number only reflects 35 per cent of the total number of women trafficked as limited resources at the time

\footnotetext{
${ }^{55}$ Ali Younes, "A tale of human traffickers and Libyan slave markets," Mail \& Guardian, November 29, 2017, https://mg.co.za/article/2017-11-29-a-tale-of-human-traffickers-and-libyan-slave-markets.

${ }^{56}$ UNODC, "Global Report on Trafficking in Persons 2016" (United Nations publication, Sales No. E.16.IV.6): 113

${ }^{57}$ Fraser, "Human Trafficking in the Democratic Republic of Congo."

${ }^{58}$ Sarah E. Mendelson, Barracks and Brothels: Peacekeepers and Human Trafficking in the Balkans, (Washington: Center for Strategic \& International Studies, 2005): 8.
} 
could identify all victims, putting the total closer to $15,000 .{ }^{59}$ Approximately 92 per cent of these women were trafficked from Albania, Moldova, Romania, and Bulgaria to Bosnia for purposes of sexual slavery. ${ }^{60}$ The brothel owners whose slaves were supplied by the traffickers followed peacekeeping troop locations, setting up in close proximity to barracks. Brothels in Kosovo and Bosnia catered to specific international clients. The brothels in the American district bore names including, "Malibu Club" and "Liberty Restaurant", while examples in the French quarters were named, "Café Bashta" and "Picasso."61 When the number of international peacekeeping troops increased in the mid-1990s, the number of trafficked women spiked. When troops were relocated, it was found that the brothels would disappear, searching for the next deployment area. ${ }^{62}$ In, "UN Peacekeeping Economies and Local Sex Industries: Connections and Implications" authors Kathleen M. Jennings and Vesna Nikolic-Ristanoic state that in the case of Bosnia, international military personnel, civilians and local police were not only customers of brothels but were also complicit in the trafficking of women in the region. ${ }^{63}$ Mendelson explains that by utilising brothels, peacekeeping troops were perpetuating in the Balkans a long military history of rape as an instrument of war. ${ }^{64}$ Jennings and Nikolic-Ristanoic take this notion a step further, explaining that the phenomenon of "rape camps" populated by local women that were present during the war was replaced by brothels populated by international women after the war to meet demand generated by peacekeepers. ${ }^{65}$ In March of 2004 , the UN responded to this issue by releasing the "Human Trafficking and United Nations Peacekeeping DPKO Policy Paper." In

\footnotetext{
59 Ibid.

${ }^{60}$ Ibid, 9.

61 Ibid, 11.

62 Ibid.

${ }^{63}$ Kathleen Jennings and Vesna Nikolic-Ristanovic, "UN Peacekeeping Economies and Local Sex Industries: Connections and Implications," MICROCON Research Working Paper. No. 17 (2009): 10.

${ }^{64}$ Mendelson, Barracks and Brothels: Peacekeepers and Human Trafficking in the Balkans, 13.

65 Jennings et al, "UN Peacekeeping Economies and Local Sex Industries: Connections and Implications," 10.
} 
the paper, the UN acknowledged that some of its peacekeeping troops had been contributing to the problem of trafficking, rather than its solution, and that measures to stop this issue were not taken seriously. ${ }^{66}$ The report stated that education of personnel and partnership with local activist groups would help to curb the issue.

When human trafficking is treated as a secondary issue or by-product of conflict or poverty its prevalence intensifies. Human trafficking is certainly connected to large-scale problems but must be treated with individual attention. As long as these conflicts displace large populations, the supply of trafficking victims remains steady. Simultaneously, and as conflict persists, the demand for soldiers, labourers, and sex slaves increases. The relationship between conflict and trafficking is darkly symbiotic and mirrors that of trafficking and cheap labour.

There is a constant and unrelenting global demand for human trafficking that is rooted firmly in wealthy countries. This global demand operates in tandem with the dominant neoliberal economic structure and the rise of globalisation. The economies of wealthy countries currently require labour from victims of human trafficking and slavery in order to function. This concept is well explained by Shelley in Human Trafficking. Shelley states that "Many of the world's citizens would never buy illegal drugs or smuggled weapons, but consumers will use the products produced by trafficking victims without thinking about why they are available at such an affordable price." 67 This concept drives traffickers, overseas sweatshops, agricultural workers, (both overseas and domestic), domestic labourers, food service businesses, sex work and pornography. ${ }^{68}$ Consumers are not thinking about the origin of these products and services.

Prostitution, for instance, may be legal in many places around the world but those who seek these

66 "Human Trafficking and United Nations Peacekeeping," DPKO Policy Paper. (2004): 1.

${ }^{67}$ Shelley, Human Trafficking: A Global Perspective, 39.

${ }^{68}$ Ibid. 
services are largely unaware of the origins of those involved. This is especially true of those who travel seeking sexual services.

International sex tourism plays a very large role in the supply and demand for trafficking. Much like the peacekeeping brothel example, the sex tourism industry caters largely to men travelling from countries all over the world. This demonstrates the international nature of trafficking, bringing the concept away from foreign obscurity. The ethical lines are blurred when considering that prostitution may be legal in the countries that those seeking sex services are travelling to, making policing difficult. The rise of globalization saw an increase in international travel and tourism. As international travel became more readily available, paedophiles were able to travel to countries seeking out child sex slaves, creating a high demand for modernizing an ancient market. ${ }^{69}$ Technological advancements have also heavily impacted the sex trafficking industry as traffickers today utilize websites to advertise sex services and communicate with potential costumers overseas via email. ${ }^{70}$ Even more modern would be the use of the popular international lodgings app, Airbnb. In 2018, the Toronto Police Service reported that there was an increasing phenomenon where traffickers were advertising homes on the app and providing women for sex services to those willing to pay. ${ }^{71}$

In Sex Trafficking and Commercial Sexual Exploitation: Prevention, Advocacy, and Trauma-Informed Practice, Lara B. Gerassi and Andrea J. Nichols state that sex trafficking, commercial sexual exploitation, and sex work are on a spectrum ranging from victimization to

\footnotetext{
${ }^{69}$ Ibid, 3.

${ }^{70}$ Ibid 41.

${ }^{71}$ Michelle McQuigge, “Airbnb rentals being used for alleged human trafficking: Toronto police," Global News, February 22, 2018, date accessed: August 10 ${ }^{\text {th }}, 2018$, https://globalnews.ca/news/4041603/airbnb-humantrafficking-toronto/.
} 
agency. ${ }^{72}$ The authors suggest that sex trafficking fits on the victimization portion of the spectrum while sex work implies agency and commercial sexual exploitation fall somewhere inbetween.${ }^{73}$ Fitting these concepts on a spectrum is important in understanding the ethical and legal boundaries surrounding the subject of sex work and trafficking.

It is impossible to argue against the statement that trafficking in persons is fundamentally wrong, but it is another issue entirely to move against trafficking in a tangible way. By purchasing goods and services provided by trafficked persons, we continue the trafficking cycle. The financial benefits provided to the corporations and consumers have proved too appealing. In this, we find the crux of the trafficking problem: too many people win out in the world of trafficking. The trafficker benefits from the sale of humans (this trade falls on the traffickers themselves, usually found at the lower end of the organizational elements of criminal hierarchy), the leaders of criminal organizations earn a profit, the recipients (employers/costumers who buy the humans) benefit from being able to offer the lowest possible costs to overseas corporations, who are then able to operate in seeming absolution of guilt, removed directly from the trafficking of persons. Finally, the product consumer wins out and in cases like the consumer who is purchasing clothing, they are so far removed from the illicit process that it does not affect them or deter them from purchase. ${ }^{74}$ What ties the primary causal drivers of slavery and trafficking today is corruption. The criminal organizations involved utilise corruption that was wrought at the end of the Cold War and nurtured by the greed that drives globalisation and the global economy.

\footnotetext{
${ }^{72}$ Gerassi, Lara B., PhD, LCSW, and Nichols, Andrea J., PhD. 2017. Sex Trafficking and Commercial Sexual Exploitation : Prevention, Advocacy, and Trauma-Informed Practice. New York: Springer Publishing Company, 7.

${ }^{73}$ Ibid.

${ }^{74}$ Shelley, Human Trafficking: A Global, 40.
} 


\section{Criminal Organizations}

From small-time local gangs specializing in sexual exploitation to large-scale multinational criminal organizations involved in varying criminal activities, traffickers come in all shapes and sizes. Corruption is a key component that keeps these organizations in operation. Criminal groups based in Russia, China, and Turkey exemplify the methods and organization used in international human trafficking. Organizations based in these countries were chosen for this discussion as Russia and China represent the impact of widespread corruption on the prevalence of human trafficking while Turkey demonstrates the impact of a developing antitrafficking stance.

Russian organized crime is rooted in a history of violence and corruption. The criminal organizations in Russia today can be traced back to the groups formed for purposes of survival in the gulags of the $18^{\text {th }}$ and $19^{\text {th }}{ }^{75}$ In the article "The Roots of Russian Organized Crime: From Old-Fashioned Professionals to the Organized Criminal Groups of Today," Serguei Cheloukhine argues, "the state was not corrupted by organized crime groups, but rather the organized crime groups became the state." $" 76$ This argument demonstrates the deep corruption and leniency for organized crime in Russia’s history. Russia's contemporary struggles with corruption, and economic instability can all be traced to the Cold War and the fall of the Soviet Union.

Slow to lose the tropes of monarchal rule, Russia experienced a violent $19^{\text {th }}$ century. Wrought in conflict, Russia's birth into the $20^{\text {th }}$ century produced a violent revolution. This revolution left a void in power and control that was quickly filled by the Soviet Union. During

\footnotetext{
75 Serguei Cheloukhine, "The Roots of Russian Organized Crime: From Old-Fashioned Professionals to the Organized Criminal Groups of Today," Crime, Law and Social Change50, no. 4 (2008): 353.

76 Ibid.
} 
the transitional period following the revolution, law enforcement was lacking, and criminal organizations were able to expand. These criminal organizations filled the governmental void during the transition following the fall of the Russian monarchy and the rise of the Soviet Union, providing services and jobs for the desperate population. ${ }^{77}$ Criminal organizations were seen as service providers to a largely neglected Russian serf class. During the Bolshevik rise, Vladimir Lenin saw these criminal organizations as champions of the working class and allied with them. Criminal organizations and their prominent members played a key role in the system of violence that controlled Soviet Russia. ${ }^{78}$ The deep partnership with the government led to these groups to transition into the legitimate business sphere.

Joseph Stalin's rise to power marked a downturn in the development of organized crime. Stalin took a hardline approach to sever the Soviet connection to the criminal underworld. The members of these organizations were forced to conform to a more legitimate organizational model that valued extreme discipline. ${ }^{79}$ This period marked the marriage of white-collar criminals and the Russian government. When the Soviet government collapsed, there was a massive resurgence in the redevelopment of classical criminal organizations. Without an overarching force to contend with, these organizations resumed overt criminal activity.

After the disbanding of the Soviet Union, the entire Eastern European Bloc was launched into turmoil. The end of the Cold War and the fall of the Soviet Union sparked chaos globally. Russia's criminal organizations began to cross international borders and bolster ties with former Soviet affiliate governments across Eastern Europe ${ }^{80}$ It is in this internationality that "Russian

\footnotetext{
${ }^{77}$ Ibid.

${ }^{78}$ Ibid, 358.

${ }^{79}$ Ibid.

${ }^{80} \mathrm{Ibid}, 363$.
} 
organized crime" actually encompasses several ethnicities with organizations considered to be part of the greater "Russian" group coming from several states. Significant migration from Russia and the Eastern Bloc saw Russian criminal ties develop in countries all over the world. ${ }^{81}$ Russian criminal organizations could again fill voids and gain deep roots in areas in which they operated. The lack of government presence meant that service provisions would again be outsourced to the criminal organizations. The shadow economy that developed saw an increasing demand for cheap labour and sexual labour. ${ }^{82}$ The shadow economy also included large-scale manufacturing that was previously controlled by the state. Manufacturing from plastic bags to motor vehicles fell into the hands of criminal enterprises and the role of the criminal business person became a cornerstone of the criminal organization. ${ }^{83}$ The result of the transnational nature of this group makes for a multi-national organization that is incredibly difficult to police.

Russian criminal organizations are not monolithic but are rather very segmented. They work together, but are not completely unified. This lends itself to individual groups having several levels of bosses, workers, and thugs. ${ }^{84}$ The bosses are connected to the governmental and business roles, while those working at the street level are akin to common thugs. ${ }^{85}$ Cheloukhine breaks these groups into three levels. The lower level groups are dedicated to committing and supervision illicit crimes. These crimes would be considered standard illegal activity like murder, kidnapping, robbery, and extortion. The second level facilitates the connection between the

\footnotetext{
${ }^{81}$ Shirō Ōkubo and Louise I. Shelley. Human Security, Transnational Crime and Human Trafficking: Asian and Western Perspectives 6, (London: Routledge, 2011): 63.

${ }^{82}$ Ibid, 63.

${ }^{83}$ Cheloukhine, "The Roots of Russian Organized Crime: From Old-Fashioned Professionals to the Organized Criminal Groups of Today," 363.

${ }^{84}$ Vsevolod Sokolov, "From Guns to Briefcases: The Evolution of Russian Organized Crime," World Policy Journal 21, no. 1 (2004): 68-74.

${ }^{85}$ Cheloukhine, "The Roots of Russian Organized Crime: From Old-Fashioned Professionals to the Organized Criminal Groups of Today, 371.
} 
lower level crimes and the economy. The third level involves the members that operate apart from the illicit activities, often holding prominent political positions. ${ }^{86}$

After 1988, the Law on Cooperatives made private ownership legal in Russia and the third level criminals were able to gain ownership of the entire economy. This gave rise to the oligarchs of Russia and the international criminal organizations that operate in countries like, Canada, the United States, Germany, and Israel. ${ }^{87}$ For Russia, the tendency toward the exploitation of women and sex trafficking is rooted in the demise of the Soviet Union. Under the rule of the Soviets, women played a prominent role in the labour force. As the social safety net was destroyed and state funding for education was eradicated, women lost their access to education and their role in the labour force. When privatisation was introduced into the Russian economy, ownership went exclusively to men. With no education, a lack of employment opportunities, and exclusion from the privatised economy, poverty was feminized in Russia. ${ }^{88}$ Many desperate women turned to sexual labour and were subsequently trafficked globally by Russian criminal organizations. Today in Russia, trafficking for forced labour is on the rise, and women are still treated as a resource to be mined and extracted by the Russian organized crime groups. ${ }^{89}$

The development of modern Chinese criminal organization follows a similar story. When communism took hold of China in 1949, criminal organizations operating within the country fell silent for decades. ${ }^{90}$ Since the fall of communism and the end of the Cold War, organized crime

\footnotetext{
${ }^{86}$ Ibid.

${ }^{87}$ Ibid.

${ }^{88}$ Ōkubo et al, Human Security, Transnational Crime and Human Trafficking: Asian and Western Perspectives, 65.

${ }^{89}$ Ibid, 64.

${ }^{90}$ Sheldon X. Zhang \& Ko-Lin Chin, "Snakeheads, mules, and protective umbrellas: a review of current research on Chinese organized crime," Crime Law Social Change 50, (2008): 177.
} 
has seen a resurgence. Loosening state controls that coincided with the disbanding of the Soviet Union saw thousands of Chinese migrants, both legal and illegal, travel to North America. ${ }^{91}$ Declining border security and control brought a rise in illegal movement. An increase in demand for cheap labour and sexual services coupled with softer borders was a breeding ground for traffickers. ${ }^{92}$ Unlike Russian groups, the Chinese focus less on sex trafficking and more on filling international cheap labour demands. The primary victims of Chinese trafficking are males sent into forced labour. ${ }^{93}$ In China, the transition away from communism resulted in privatisation and a massive increase in wealth that was concentrated on major cities. This meant that rural areas were left rudderless and poor, making for a vulnerable population. ${ }^{94}$ Chinese groups also allocate considerable resources to smuggling. This again diverges from the Russian model, where trafficking victims are treated as a resource. In China, those sent abroad under both smuggling and trafficking circumstances are meant to send earnings back into the Chinese economy. ${ }^{95}$ The Chinese groups treat victims as more of a long-term investment while the Russians operate with a model that treats them as a single sale commodity.

The Chinese criminal groups operate in a similar fashion but contrary to general assumptions, Chinese trafficking is not structured within Chinese criminal organizations (known as "Triads"). As discussed by Sheldon Zhang and Ko-Lin Chin in their article "Snakeheads, mules, and protective umbrellas: a review of current research on Chinese organized crime," extensive research has revealed that smuggling and trafficking in China are primarily facilitated

\footnotetext{
${ }^{91}$ Cheloukhine, "The Roots of Russian Organized Crime: From Old-Fashioned Professionals to the Organized Criminal Groups of Today," 371.

92 Ibid.

${ }_{93}^{3}$ Ōkubo et al. Human Security, Transnational Crime and Human Trafficking: Asian and Western Perspectives, 68.

${ }^{94}$ Ibid, 63.

95 Ibid, 64.
} 
by 'freelance' criminals who develop their own networks through international relationships. ${ }^{96}$ Those who deal directly in trafficking operate in a hierarchy split into Big Snake Heads and Little Snake Heads. ${ }^{97}$ The Big Snake Heads invest money into trafficking and smuggling from overseas. They are usually businessmen with wealth, power and connections to the government but completely disconnected from the act of trafficking. The Little Snake Heads are directly involved in the act of trafficking, smuggling, and recruiting. They operate in small operatives positioned in the field.

Turkish organized crime groups have roots in the Ottoman Empire. As with the Russian organizations, the Turkish started as social service providers, filling the void left by the Ottoman Empire in providing necessities and services to the poor populations living in rural areas. ${ }^{98}$ Starting as small groups located primarily within rural communities, members known as 'hoodlums' and 'vigilantes' would offer protection, steal food, and provide shelter for the poor communities. These groups eventually migrated into larger cities and assumed more prominent positions. ${ }^{99}$ When the Ottoman Empire began to form smaller states and delegate responsibilities to various Sultans in the $16^{\text {th }}$ and $17^{\text {th }}$ century, criminal organizations gained more power. The transitional period following the First World War and the end of the Ottoman Empire saw another power vacuum in which criminal groups again assumed a more prominent position. ${ }^{100}$ By the fall of the Soviet Union, Turkish groups were capitalizing on the waning political

\footnotetext{
${ }^{96}$ Zhang et al, "Snakeheads, mules, and protective umbrellas: a review of current research on Chinese organized crime," 182.

${ }^{97}$ Sheldon Zhang and Ko-Lin Chin, "Enter the Dragon: Inside Chinese Human Smuggling Organizations," Criminology 40, no. 4 (2002): 738.

${ }^{98}$ Mahmut Cengiz, "The Globalisation of Turkish Organized Crime and the Policy Response," ProQuest Dissertations Publishing, 2010, 45-46.

${ }^{99}$ Ibid, 46.

${ }^{100}$ Ibid, 49.
} 
structures in former Soviet regions. The Turkish also capitalized on the impoverishment of women in the rural regions of Russia, using tactics to recruit women for trafficking.

The end of the Cold War and the subsequent collapse of communism coupled with globalisation allowed for the rise of criminal organizations in both China and Russia. For the Turkish groups, unencumbered by communist regimes, the end of the Cold War and fall of the Soviet Union represented an opportunity to penetrate surrounding countries with waning border control and governmental regulations. These organizations were able to truly penetrate all aspects of society in their respective states. For the Russia organizations, human trafficking over the last two decades has been based almost exclusively on women for the sex trade. Today, labour trafficking is on the rise.

The US Department of State reported that over the past five years Russia has been a prominent source, transit, and destination country for trafficking. Those trafficked into Russia come from other parts of the country, other European countries, Central Asia, or South East Asia. For these international victims, forced labour is the cardinal form of exploitation. ${ }^{101}$ The foreign labour force involved in the logging, manufacturing, and waste management industries were found to be populated by irregular migrants experiencing conditions comparable to typical trafficking cases. The withholding of documents, non-payment, and physical abuse were all reported in these industries. ${ }^{102}$

Sex trafficking remains prevalent as women and children primarily from Ukraine, Moldova, Vietnam, Nigeria, and Central Asia were found to be trafficked into Russia for sex

\footnotetext{
${ }^{101}$ US Department of State, Trafficking in Persons Report, June 2017, date accessed: July $10^{\text {th }}, 2018$, https://www.state.gov/documents/organization/271339.pdf, 337.

${ }^{102}$ Ibid, 338.
} 
work in hotels, brothels, and saunas, and advertised on internet markets. Russia as a source country sees women and children trafficked into North America, North East Asia, Europe, Central Asia, Africa, and the Middle East. Russian children from state and municipal orphanages were especially vulnerable to exploitation in child pornography, forced criminality, sexual slavery, and child soldiering (primarily in Middle Eastern conflicts). ${ }^{103}$ Russian traffickers utilize all means of transportation, and are heavily aided by corrupt state officials who often turn a blind eye. Corruption within the members of the FSB (Russian Security Police) helps to facilitate border crossings. ${ }^{104}$ Officials in more high-ranking positions offer protection to traffickers and actively aid in the return of emancipated victims to their exploiters. ${ }^{105}$

Trafficking for Chinese operations does involve women for the sex trade, but more prominently men for international forced labour camps. Trafficking in China today is fueled by demand generated from government sanction forced labour institutions. The government in China had been operating an initiative knows as, "Re-education through labour (RTL)." RTL facilities were abolished in 2013 as they involved large-scale human rights abuses and elements of forced labour. A 2015 UN report found that although several RTL facilities had been shut down, several were converted into drug-rehabilitation facilities where forced labour was again prevalent. ${ }^{106}$ The Chinese government has also been exposed for sanctioning work-study programs for children where children were forced to work in factories. Men, women, and

\footnotetext{
${ }^{103}$ Ibid.

${ }^{104}$ Ōkubo et al, Human Security, Transnational Crime and Human Trafficking: Asian and Western Perspectives, 66.

${ }^{105}$ US Department of State, Trafficking in Persons Report, 338.

${ }^{106}$ Ibid, 128.
} 
children are forced to work in brick kilns, coal mines, and factories. Many of these institutions are technically illegal but allowed by law government enforcement. ${ }^{107}$

Chinese women and children are subjected to both domestic and international sex trafficking. The majority of these victims are taken from rural areas of China and trafficked into the larger cities with promises of job offers or better living conditions. ${ }^{108}$ Corruption within the Public Security Bureau helps to facilitate the movement of rural Chinese populations around the country and internationally. ${ }^{109}$ These victims are also taken by means of force, physical threats, confiscation of documents or charged high travel fees and locked into debt labour. ${ }^{110}$

According to the US Department of State report, Turkey is a destination and transit country for trafficking. The report states that Turkey is also a source country, but to a lesser extent. ${ }^{111}$ Today, the majority of trafficking victims in Turkey are Syrian. This can be attributed to the large number of refugees hosted by Turkey. This refugee population is especially vulnerable to traffickers. The report suggests that the use of social media as a recruitment tool for traffickers is increasing in Turkey. Traffickers employ women to manage the social media accounts, and trick young women into the sex trade. ${ }^{112}$ Both Chinese and Russian groups rely heavily on corruption to sustain trafficking and smuggling activities.

The international nature of these operations offer a strong point in arguments surrounding immigration and the potential threats that arise from mass migration. Mark Krikorian in "Mass Immigration Defeats Homeland Security" argues that one problematic element to mass migration

\footnotetext{
107 Ibid.

108 Ibid.

${ }^{109}$ Ōkubo, Human Security, Transnational Crime and Human Trafficking: Asian and Western Perspectives, 66.

${ }^{110}$ Ibid.

${ }^{111}$ US Department of State, Trafficking in Persons Report, 402.

112 Ibid.
} 
is the development of enclave communities. Krikorian suggests that enclave communities have the potential to unwittingly provide cover for 'attackers' ${ }^{113}$ Krikorian is writing in the context of terrorist threats but uses the example of the Mafia in Italian enclaves in the United States that is applicable to a discussion on organized crime. The Chinese criminal organizations utilise freelance criminals who are positioned in Chinese communities to establish international connections and relationships. For the Russian groups, who encompass several ethnicities under the umbrella of the former Soviet Union, international enclaves and diasporic communities offer protection. It is extremely difficult to police this sort of activity, especially when responsible governments must weigh the positive and negative aspects of the development and maintenance of ethnic enclaves. The international response to human trafficking has been widespread in its denouncement, but methods and approaches to combat trafficking vary. Today pressure rises for the international community to combat human trafficking, especially connected to women and children trafficked into the sex trade. Definitions are imperative in understanding the international legal reaction to combating these crimes. Chief among them is the UN's Palermo Protocols, which deal directly with the trafficking of weapons and humans as well as the smuggling of humans.

\section{The Palermo Protocols}

\footnotetext{
${ }^{113}$ Mark Krikorian, "Mass Immigration Defeats Homeland Security," In Immigration Policy and the Terrorist Threat in Canada and the United States, ed. Martin Collacott and Alexander A. Moens, 37-52. Vancouver: Fraser Institute, 2008, 45.
} 
As the Palermo Protocols are based on the overarching protocol of the United Nations Convention on Transnational Organized Crime, it is important to explore the convention on organized crime first. ${ }^{114}$ The convention on organized crime defines organized crime as follows:

"Organized criminal group" shall mean a structured group of three or more persons, existing for a period of time and acting in concert with the aim of committing one or more serious crimes or offences established in accordance with this Convention, in order to obtain, directly or indirectly, a financial or other material benefit...For the purpose of paragraph 1 of this article, an offence is transnational in nature if: It is committed in more than one State; It is committed in one State but a substantial part of its preparation, planning, direction or control takes place in another State; It is committed in one State but involves an organized criminal group that engages in criminal activities in more than one State; or It is committed in one State but has substantial effects in another State. ${ }^{115}$

As stated by transnational crime expert Louise Shelley, these definitions provide the base on which the Palermo Protocols were developed. The definition of an organized criminal group is important in the context of human trafficking as people often consider human trafficking to be the work of large international criminal organizations with several members and global ties. Those who facilitate the trafficking of humans often operate in small, covert groups. Paramount in understanding the prevalence of human trafficking is being aware of the fact that traffickers and trafficking operations range from local gangs to international criminal organizations. For example, in 2017, Canada saw a trafficking scandal that included only four people. Two Toronto men and a woman who had trafficked a 21-year-old woman into the country for work in the Toronto sex industry. ${ }^{116}$ Comparing this form of trafficking to the large-scale crime carried out by larger groups utilizing international networks supplying massive sex industries in Thailand or

\footnotetext{
114 Shelley, Human Trafficking: A Global Perspective, 9.

115 UN General Assembly, “Convention against Transnational Organized Crime,” November 2, 2001 (New York: United Nations Publications): 25-26.

116 "Woman, 2 men charged in Toronto human trafficking case," Global News, May 16, 2018, date accessed: May 25, 2018. https://globalnews.ca/news/4212567/3-charged-toronto-human-trafficking-case/.
} 
forced labour camps in India can be problematic as the methods for combating local scale Toronto example would vary drastically at the international scale.

The Palermo Protocols are an attempt to couple three separate protocols on trafficking in humans and weapons and the smuggling of migrants. The Palermo Protocols include the Protocol to Prevent, Suppress and Punish Trafficking in Persons, especially Women and Children; the Protocol against Smuggling of Migrants by Land, Sea and Air; and the Protocol against the Illicit Manufacturing and Trafficking of Firearms, Their Parts and Components and Ammunition. Although comprehensive and detailed, the Palermo Protocols prove difficult to apply on a state to state basis due to the varying and complex nature of individual state sovereignty. They offer an effective frame for trafficking laws, but they do not provide an answer to the trafficking problem.

Under subparagraph (a) in the 2000 Protocol to Prevent, Suppress and Punish Trafficking in Persons Especially Women and Children, trafficking is defined as:

“...the recruitment, transportation, transfer, harbouring or receipt of persons, by means of the threat or use of force or other forms of coercion, of abduction, of fraud, of deception, of the abuse of power or of a position of vulnerability or of the giving or receiving of payments or benefits to achieve the consent of a person having control over another person, for the purpose of exploitation. Exploitation shall include, at a minimum, the exploitation of the prostitution of others or other forms of sexual exploitation, forced labour or services, slavery or practices similar to slavery, servitude or the removal of organs..."117

In this definition, the terms 'force' and 'exploitation' are important to the influence of this protocol on the development of national law in various countries as both terms can be defined on a state to state basis, influenced by traditional laws, culture, and religion. Although treated as an

\footnotetext{
${ }^{117}$ United Nations, "Protocol to Prevent, Suppress and Punish Trafficking in Persons, especially Women and Children, Supplementing the United Nations Convention Against Transitional Organized Crime," UNCJN, 2000.
} 
outline, these definitions are paramount in forming laws that are capable of prosecuting those guilty of trafficking in persons. These definitions also dictate the direction that a state may take in the eradication of trafficking. The Protocol on trafficking, in the statement of purpose, cites the prevention of trafficking, the protection of victims, and cooperation among states as the main objectives of the protocol. The definition goes on to stipulate the application of consent in the context of trafficking in subparagraph (b): "The consent of a victim of trafficking in persons to the intended exploitation set forth in subparagraph (a) of this article shall be irrelevant where any of the means set forth in subparagraph (a) have been used..."118 The concept of consent is extremely important in this definition. Consent is the main difference present in the comparison between the definition of trafficking and that of smuggling. It is often the case that victims of trafficking have not been abducted or threatened with physical force. Such victims are convinced by traffickers that their cooperation will bring them to a better life, and so they travel with consent. This form of deception is often employed when taking young children from their homes, convincing the parents of the child that the child will experience a higher quality of life overseas, only to be forced into servitude. This is also true of young women deceived into the sex trade. Lies will be told regarding the agency that a victim will have upon arrival in the new country. Often, they are convinced that they will work to repay a debt, only to find the debt is so large and the wages are so minuscule that repayment is futile. This protocol has accounted for this form of deception by discounting consent wrought under the influence of traffickers.

The rights of the child play a fundamental role in the discussion of human trafficking, especially in relation to the United Nations. In November 1989, the UN passed the Convention

\footnotetext{
${ }^{118}$ Ibid.
} 
on the Rights of the Child. This convention outlines the fundamental rights that children hold regardless “...of his or her parent's or legal guardian's race, colour, sex, language, religion, political or other opinion, national, ethnic or social origin, property, disability, birth or other status. ${ }^{" 119}$ Amongst the 54 articles discussed in the convention, the safety, protection, and health of the child are addressed. It explores the concept of nationality and religion, stating that the child is free to choose who they worship. According to the convention, responsibility for the adherence to the child's rights lies with the parents and the government of the place in which the child is living. When addressing the trafficking of children, the trafficking protocol subparagraph (c) states, "The recruitment, transportation, transfer, harbouring or receipt of a child for the purpose of exploitation shall be considered "trafficking in persons" even if this does not involve any of the means set forth in subparagraph (a) of this article..." ${ }^{120}$ Subparagraph (c) represents a harkening back to the spirit of child rights, making people trafficking children easier to apprehend. However, it is difficult to apply the salient points of these protocols to the laws of individual states. The legal application is further complicated when the distinction between trafficking and smuggling is introduced.

In the contemporary contexts including news media outlets and academic discussions, "human trafficking" is often discussed alongside "human smuggling". Although both of these terms refer to an illegal means of transportation these terms have been given respective definitions by the UN for the sake of clarity in international law. The UN definition of human trafficking emphasizes the use of force as a means to coerce innocents into nefarious labour. Human smuggling, as defined by the UN in the Protocol Against the Smuggling of Migrants by

\footnotetext{
${ }^{119}$ United Nations, "Convention on the Rights of the Child," Treaty Series 1577, 1989.

${ }^{120}$ United Nations, "Protocol to Prevent, Suppress and Punish Trafficking in Persons, especially Women and Children, Supplementing the United Nations Convention Against Transitional Organized Crime.”
} 
Land, Sea and Air is, “...the procurement, in order to obtain, directly or indirectly, a financial or other material benefit, of the illegal entry of a person into a State Party of which the person is not a national or permanent resident..." ${ }^{121}$ The fundamental difference between these definitions is that human trafficking involves the assumed violation of human rights. The UN definition of human smuggling brings agency into the illegal action. These definitions are dangerous. It is important to realize that these two terms are not easily divided. Regardless of agency, smuggling puts refugees and migrants in dangerous situations that often lead to trafficking. Physical abuse, starvation, overcrowding, and unsafe transpiration are not uncommon in smuggling operations. ${ }^{122}$ Smugglers are often able to change the terms of a smuggling agreement, midoperation by asking for further payment or diverting the destination. Smuggling is an illegal act for both the smuggler and the smuggled. Despite the illegal nature of smuggling, the smuggler is not held accountable for services rendered and the person being smuggled does not have the ability to go to the authorities because in doing so, they would implicate themselves. It is dangerous to suggest that trafficking and smuggling are completely separate. Although smuggling denotes an air of innocence when associated with small-time smugglers helping refugees (in some cases, fraudulent) escape violence, these refugees are often left in precarious situations, ripe for further exploitation. In this blurred line between trafficking and smuggling lies the crux of the enforcement problem.

According to the UN 2016 Global Report on Trafficking in Humans, in 2003, 33 countries had created laws based on the UN Trafficking in Persons Protocol. That number has

\footnotetext{
${ }^{121}$ UN Smug United Nations, "Protocol Against the Smuggling of Migrants by Land, Sea and Air, Supplementing the United Nations Convention Against Transnational Organized Crime." UNCJN, 2000.

${ }^{122}$ Sally W. Stoecker, and Louise I. Shelley, Human traffic and transnational crime: Eurasian and American perspectives, (Lanham: Rowman \& Littlefield, 2005): 66.
} 
since increased to 158 , representing a shift in conviction rates. ${ }^{123}$ Although these conviction rates are still extremely low, the UN found that there was a correlation between the number of years since a country's implementation of anti-trafficking laws and that country's conviction rates. ${ }^{124}$ Although these protocols offer a solid framework on which countries can develop laws, it is difficult to enforce the core tenets because of the differences in legal protocols and bureaucracy among states.

The sovereignty held by states allows the creation of laws on a national basis largely apart from international rules. Although ratification of the Palermo Protocols suggests that a country will adhere to its core tenets, there is little enforcement after the fact. The focuses of individual countries vary, with some countries selecting certain tenets to exact in national law while disregarding others. As an example, focusing national laws on apprehending traffickers may result in stricter borders and thus have an adverse effect on victims of trafficking. This is a problem seen frequently when assessing the success of states in the persecution of traffickers. When looking to Canadian cases, critics like Romesh Hettarachchi, Amy Stephens, and Sung Hyun Yun assert that the country's laws focus on the apprehension and prosecution of traffickers while ignoring the victims of trafficking. ${ }^{125}$ This notion is echoed by Jacqueline Oxman-Martines and Jill Hanley in "A Follow-up Study of Canadian Policy on Human Trafficking: Impacts of the Immigration and Refugee Protection Act," who suggest that victims of human trafficking are made more vulnerable as immigration laws criminalize victims, allowing for traffickers to retain

\footnotetext{
${ }^{123}$ UNODC, "Global Report on Trafficking in Persons 2016” (United Nations publication, Sales No. E.16.IV.6) Date accessed: February $10^{\text {th }} 2018$, https://www.unodc.org/documents/data-andanalysis/glotip/2016_Global_Report_on_Trafficking_in_Persons.pdf, 1. experiences of local service providers," in Labour Migration, Human Trafficking and Multinational Corporations: The Commodification of Illicit Flows, ed. Ato Quayson and Antonela Arhin, 152-158, (London: Routledge, 2012): 153.
} 
power over victims who fear deportation. ${ }^{126}$ Hettarachchi et al. attribute this vulnerability to the notion that without a Temporary Resident Permit (TRP), victims of trafficking in Canada cannot receive support and may face deportation, giving traffickers leverage. ${ }^{127}$ According to the Government of Canada, TRPs are to be used by Canadian Border Officers "only in exceptional circumstances and when the need of the individual to enter or remain in Canada is compelling and sufficient to overcome any risks that they might pose." 128 These permits can be given even if the person in question does not meet the requirements for the Immigration and Refugee Protection Act. ${ }^{129}$ Hettarachchi et al. go on to criticize the TRP system, citing problems with victim identification and the insensitive nature of the interview processes which determine eligibility. They suggest that "strengthening inter-agency relationships," training officers on victim identification, and expanding the funding and services allocated toward victims of trafficking would help to foster reintegration and resettlement for victims within Canada. ${ }^{130}$ Although the criticism levelled against the TRP system is compelling, the solutions offered were problematic. It may be more logical to identify and develop a more specific system for handling victims of trafficking as the allocation TRPs rely heavily on the discretion of individual border officers.

In the Canadian case, it seems that the victims are negatively impacted in order to retain stronger abilities in prosecuting the perpetrators, but the potential approaches to solving these

\footnotetext{
${ }^{126}$ Jacqueline Oxman- Martinez \& Hanley, Jill, “A Follow-up Study of Canadian Policy on Human Trafficking: Impacts of the Immigration and Refugee Protection Act," (Montreal: McGill University, 2004): 5.

${ }^{127}$ Stephens et al, "Responding to labour trafficking, Suggestions for experiences of local service providers," 153.

128 "Temporary Resident Permits (TRPs)" Government of Canada, date modified, August 1 1 , 2015, date accessed: August $13^{\text {th }}, 2018$. https://www.canada.ca/en/immigration-refugees-citizenship/corporate/publicationsmanuals/operational-bulletins-manuals/temporary-residents/permits/when-to-consider-issuing.html.

129 Ibid.

${ }^{130}$ Stephens et al, "Responding to labour trafficking, Suggestions for experiences of local service providers," $156-$ 158.
} 
issues are extremely complex. The simultaneous prosecution of trafficking and support for victims requires a fine balance, one that seems unattainable in nations bogged down in bureaucracy and long-standing legal traditions. While it is imperative that researchers remain steadfast in developing sound strategies in stopping this terrible crime, the rights of the victim must be considered. Though international protocols provide a strong framework, steps must be taken to enforce action at the national level in all countries that stand against trafficking. The countries of Europe and Western Asia are a prime example of the complexity applying of trafficking laws.

The presence of longstanding cultural traditions and legal systems prove problematic when dealing with modern trafficking laws. Assessing the criminalization of trafficking in persons for Western and Central Europe, the 2016 UN Report on Human Trafficking stated that "nearly all the countries in the region [consisting of Ireland, the United Kingdom, Norway, Sweden, Finland, Denmark, the Netherlands, Belgium, Germany, France, Switzerland, Austria, Portugal, Spain, Andorra, Italy, Malta, Greece and Turkey] had enacted a specific trafficking in persons offence..."131 . Aside from Germany and the Netherlands (both countries having relevant laws that predate the UN protocol on trafficking), all the countries in the area described enacted laws in correspondence with the UN protocol on trafficking between 2003 and 2004. ${ }^{132}$ Excepting Andorra, these countries reported at least one trafficking conviction between 2012 and 2014, with numbers ranging from under 10 to over 150 per year. The region also had a prosecution average of 62 per cent with " 32 per cent of those prosecuted received first instance convictions. About 20 per cent of the persons who were initially investigated were convicted in

\footnotetext{
${ }^{131}$ UNODC, "Global Report on Trafficking in Persons 2016," 77.

${ }^{132}$ Ibid.
} 
the court of first instance in Western and Southern Europe.”133 In Estonia, Latvia, Poland, Czechia Slovakia, Hungary, Slovenia, Romania, Serbia, Montenegro, Bulgaria, Albania, and Macedonia, the fact that these countries had enacted laws prior to the UN Protocol resulted in higher conviction averages. Bulgaria and Romania reported conviction numbers of 60 to 100 per year while these countries saw a "33 per cent of the persons suspected of or investigated for trafficking in persons receive first instance court convictions... Looking at the criminal justice process in more detail, 64 per cent of investigated persons are prosecuted, and 56 per cent receive first-instance convictions." 134 These results demonstrate that countries with maturing laws on trafficking tend to see higher conviction rates.

Similar numbers were found in the regions of Eastern Europe and Central Asia, consisting of Russia, Kazakhstan, Belarus, Ukraine, Uzbekistan, Moldova, Armenia, Azerbaijan, Georgia, Kyrgyzstan, and Tajikistan. The report states that half the countries in this region had legislation that predated the UN protocol, with six counties introducing legislation on trafficking prior to 2003, five countries between 2004 and 2008 and one county between 2008 and $2012 .^{135}$ The majority of the countries in Eastern Europe and Central Asia saw conviction numbers at 10 to 30 per year. ${ }^{136}$ These conviction numbers represent the lower end of conviction rates when compared to the regions discussed above.

Anti-trafficking laws in Ukraine suffer from issues in implementation. Anti-Trafficking laws in the country have been present in the legal constitution since the late 1990s, indicating

\footnotetext{
133 Ibid.

134 Ibid, 83.

135 Ibid, 89.

136 Ibid.
} 
early consideration anti-trafficking legislation. ${ }^{137}$ Despite this, early drafts of anti-trafficking laws in Ukraine suffered from issues with funding, implementation, and specificity. Even after Ukraine was a signatory to the UN protocol against trafficking, these issues persisted. ${ }^{138}$ The country continues to struggle with laws surrounding sexual labour, and as a consequence, trafficking laws fail to produce convictions. The presence of Russian traffickers in Ukraine and the firm grip that the Russian government holds on the region also impacts anti-trafficking measures today. Problems aside, the ratification of these protocols does represent a step in the right direction. Many countries have abstained from implementing laws on trafficking and show no signs of change. The complexity of modern slavery and trafficking make it very difficult to police, often bleeding into the economy and involving corrupt police, security and government officials. The international frameworks meant to deal with trafficking in humans offer a strong basis for anti-trafficking laws but because the crime affects several areas of society and transcends borders, these frameworks fail to be implemented in a meaningful way. The financial gains generated by modern slavery and human trafficking demonstrate how lucrative this crime can be for the criminals involved. These numbers are taken largely from UN reports. This is because these reports offer the most comprehensive and contemporary outlook on modern slavery and trafficking. Although these sources are politically driven, part of the challenge when studying trafficking is the lack of reliable information, these sources have demonstrated sound methodology and are the most reliable sources available.

\section{Contemporary Statistics}

\footnotetext{
${ }^{137}$ Yevhenia Lutsenko, Lydia Matiaszek, Shivaum Scanlan, Inna Shvab. "Trafficking in Ukraine: An Assessment of Current Responses," UNICEF, Kyiv: UNICEF, 2005, 23.

${ }^{138}$ Ibid, 27.
} 
Free the Slaves estimates that global slavery generates $\$ 150$ billion USD in illicit profits per year. ${ }^{139}$ The forms of modern slavery include forced labour, bonded labour, child slavery and human trafficking. ${ }^{140}$ Anti-Slavery estimates that there are approximately 40.3 million people in modern slavery today. Of those 40 million, 10 million are children, 24.9 million perform forced labour, 15.4 million are in forced marriages, and 4.8 million are forced into sexual exploitation. ${ }^{141}$ A report released by the European Parliament suggests that 20.9 million people are trafficked per year, resulting in a profit of $\$ 117$ billion USD. ${ }^{142}$

Human trafficking is a form of slavery and can often lead to exploitation in other forms of slavery. As an example, a person could be trafficked into sexual slavery or forced labour. The European Parliament suggests that 22 per cent of victims are trafficked for purposes of sexual exploitation, 68 per cent for forced labour, and 10 per cent for other reasons. ${ }^{143}$ The use of violence, deception or coercion is paramount in defining the crime unless the trafficking incident involves children. In such cases moving the child into an exploitative situation constitutes trafficking. ${ }^{144}$ It is important to note that trafficking can take place within national borders and is not exclusively international. 43 per cent of trafficking occurs domestically. The global total numbers for victims of trafficking are 51 per cent female, 25 per cent children, and 21 per cent male. Statistics on traffickers suggest that 63 per cent are men and 37 per cent are women. ${ }^{145}$ The

\footnotetext{
139 “Global Slavery Facts," Free the Slaves, last modified, 2018, date accessed: July $15^{\text {th }}, 2018$, https://www.freetheslaves.net/.

140 "What is modern slavery?" anti-slavery, last modified, 2018, date accessed: July $15^{\text {th }}, 2018$, https://www.antislavery.org/slavery-today/modern-slavery/.

${ }^{141}$ Ibid.

142 "Human Trafficking: More than 20 million victims," European Parliament, last modified October 18, 2016, date accessed July $15^{\text {th }} 2018$, http://www.europarl.europa.eu/news/en/headlines/world/20161014STO47261/humantrafficking-more-than-20-million-victims-worldwide.

${ }^{143}$ Ibid.

144 "What is human trafficking?" anti-slavery, last modified, 2018, date accessed: July $15^{\text {th }}, 2018$, https://www.antislavery.org/slavery-today/human-trafficking/.

${ }^{145}$ Ibid.
} 
Asia Pacific region makes up the majority of victims at 56 per cent followed by, Africa at 18 per cent, South America and the Caribbean at 9 per cent, the EU at 7 per cent, the rest of Europe and Central Asia at 7 per cent, and the Middle East at 3 per cent. People are trafficked for a plethora of nefarious reasons, most of which fall under the umbrella of forced labour.

Forced labour is described as forcing people to work against their will. Almost all forms of modern slavery involve some form of forced labour. ${ }^{146}$ Forced labour can include agriculture, fishing, domestic work, construction, resource extraction, manufacturing, and sexual exploitation. ${ }^{147} 24.9$ million people are trapped in forced labour enslavement worldwide, with 11.7 million in Asia and the Pacific, 3.7 million in Africa, 1.8 million in Latin American and the Caribbean, and 1.5 million in developed economies like Japan, Canada, the United States, the EU, Australia, and New Zealand. ${ }^{148}$ Victims are forced into labour through a multitude of methods ranging from physical and mental abuse to financial control. When looking specifically at financial control, the concept of debt bondage or bonded slavery is relevant.

Bonded slavery is connected with both human trafficking and forced labour. Almost 50 per cent of forced labour victims are bound by debt. This allows traffickers and slavers to keep victims working toward the repayment of their debt. In the case of trafficking or smuggling, perpetrators will demand work as payment in the form of labour for the act of moving them into a new country or region. The variations and complexity present in the study of modern slavery and human trafficking make these subjects very difficult to combat. In order to effectively combat modern slavery, human trafficking must be addressed as well. As trafficking and slavery

\footnotetext{
146 "What is forced labour?" anti-slavery, last modified, 2018, date accessed: July $15^{\text {th }}, 2018$, https://www.antislavery.org/slavery-today/forced-labour/

${ }^{147}$ Ibid.

${ }^{148}$ Ibid.
} 
overate in a supply and demand relationship, in order to end the supply circulated by trafficking, there must be an end to the demand created by global slavery.

No scholars present in the border security debate would argue against the end of human trafficking. Opinions diverge regarding how to end the trade in humans, and the global demand for slave labour. A distinction must be made between long-term and short-term approaches to end the prevention and end of these crimes. It must be recognized that long-term solutions take time and need to be supplemented with short-term solutions. Ending the dependency and desperation created by the modern neoliberal global economy is an admirable suggestion as traffickers leverage the desperations of refugees displaced by crippling poverty and lack of opportunity. To end regional conflict born of globalisation and the coveting of natural resources would curb trafficking demands but it is a lofty goal. The world of academia has no shortage of ideas and frameworks to end these crimes on a grand scale, but short-term solutions are lacking.

\section{Perspectives on Combating Trafficking and Modern Slavery}

Anti-Slavery, the UN, the ILO, and the US Department of State take similar approaches to ending trafficking. Anti-Slavery suggests that efforts should be made to address the root causes of modern slavery. The widespread criminalization of all elements of slavery, engaged national authorities, governmental protections, access to safe work opportunities, freedom of association, immigration policies that eliminate the vulnerability of migrants, the upholding of the rights of the child, and transparent business models are all listed within the Anti-Slavery Charter. ${ }^{149}$ Similarities in the points laid out by Anti-Slavery can be seen in the UN approach. The UN stresses the importance of national law enforcement, acknowledging that international

\footnotetext{
149 "What is modern slavery?" anti-slavery.
} 
frameworks are not enough to curb the supply of and demand for slavery. In several cases, the UN demonstrates that nations that implemented anti-trafficking laws earlier typically see higher conviction rates. ${ }^{150}$ This means that countries must be held accountable. This is easier said than done as many of the countries with the worst instances of trafficking hold a tremendous amount of power on the global stage, and cannot be persuaded to act.

The US Department of State's report on trafficking takes a relatively aggressive approach when addressing trafficking states in individual countries. While the UN Report on Trafficking includes a detailed section on the regional states of trafficking, the US State Department focuses on individual countries and their efforts, or lack thereof. Through a three-tier ranking system, governments are ranked based on the level of commitment demonstrated in addressing human trafficking issues under the Trafficking Victims Protection Act (TVPA). ${ }^{151}$ Governments placed on tier one fully meet the minimum requirements stipulated in the TVPA. Governments in tier two do not fully meet the requirements but are making "significant efforts to bring themselves into compliance with those standards." 152 Tier three governments do not meet the minimum requirements and do not show any attempt to meet the requirements. Both China and Russia are placed on tier three, with recommendations based on a need for resources allocated toward apprehending and prosecuting traffickers. Both China and Russia demonstrate the shortcomings of international frameworks and protocols. Both countries rarely comply with international human rights standards and operate at will. Turkey represents an interesting example in the Department of State's report. Ranking on tier two, Turkey does not fully meet the minimum requirements, but the government has demonstrated that efforts are being made. The government

\footnotetext{
${ }^{150}$ UNODC, "Global Report on Trafficking in Persons 2016."

${ }^{151}$ The TVPA was introduce in 2000 by the Unites States to combat trafficking and involuntary servitude.

${ }^{152}$ US Department of State, Trafficking in Persons Report, 28.
} 
introduced an action plan against trafficking, identified more victims, and trained government personnel on trafficking issues. ${ }^{153}$ Turkey's recent attempts at combatting trafficking fit into a larger history of attempts are rectifying human rights violations. Turkey's history with the European Union and attempts to adhere to suggestions made by the EU demonstrate some positive action towards international cooperation against trafficking. In the case of Turkey, the international community has some influence over the Turkish government and its actions, resulting in progress from an anti-trafficking perspective. The unification of states is paramount in combating modern slavery and trafficking as helps to create a uniform approach. Utilizing the global economy to combat trafficking might also be possible through interstate cooperation.

In "Free Labor! A Labor liberalization solution to modern trafficking in humans", Karen E. Bravo argues that the liberalization of labour in the global economy could be used to "harness the power of the market to combat human trafficking." ${ }^{\prime 154}$ To Bravo, the global economy needs to better recognize the importance of labour in the production of capital. ${ }^{155}$ This idea is related to the concept discussed in the causal section of this paper. Capital is largely able to transcend borders, while the humans who produce the capital are rooted in place by border security and migration laws. With attention to this reality, Bravo suggests that the recognition of labour, and the ability of labourers to follow market forces and the flow of labour demand would help to eliminate trafficking. It is the labourer's pursuit of the global demand for labour that leads to trafficking. This idea connects with Kevin Bales' study, "What Predicts Human Trafficking?" Bales found that the presence of opportunity in a country made it an appealing country to be

\footnotetext{
${ }^{153} \mathrm{Ibid}, 400$.

${ }^{154}$ Karen E. Bravo, "Free Labor! A Labor Liberalization Solution to Modern Trafficking in Humans," Transnational Law \& Contemporary Problems 18, no. 3 (2009): 1.

${ }^{155}$ Ibid, 2.
} 
trafficked into. ${ }^{156}$ Bravo suggests that labourers are constantly seeking to trade their labour in the global economy. The global economy requires this pursuit, as it requires trafficking to produce cheap labour. It is in this fact that Bravo's argument is rooted. As long as the economy requires cheap labour, trafficking will continue and so some responsibility must be on wealthy powers and their hold on the economy.

Bravo’s approach intersects with Daria Davitti’s argument in “Shirking Responsibilities: Receiving Countries and the Structural Causes of Conflict-Related Child Trafficking," Davitti argues that trafficking manifests in conflict/post-conflict countries, and that attempts to stop trafficking in these regions are rooted in short-term solutions. ${ }^{157}$ Davitti suggests that the causes of trafficking can be identified and mitigated through a "more thorough analysis of the 'longer chain of causation' between counties involved along the trafficking chain..."158 This argument puts pressure on the destination country, essentially sharing the burden of cause between the sending and receiving country. The responsibility of the destination country should not be limited exclusively to catching traffickers and smugglers at the border.

Davitti uses the relationship between Afghanistan and the United Kingdom to demonstrate the importance of this burden of cause. Afghanistan is a country that is in a perpetual state of conflict and post-conflict. ${ }^{159}$ During times of conflict, displaced Afghans, especially children, become targets for traffickers. Young boys are kept in conflict zones as

\footnotetext{
${ }^{156}$ Kevin Bales, "What predicts human trafficking?" International Journal of Comparative and Applied Criminal Justice 31. No 2 (2007): 277.

${ }^{157}$ Daria Davitti, "Shirking Responsibilities: Receiving Countries and the Structural Causes of Conflict-Related Child Trafficking," In Human Trafficking in Europe, ed. Gillian Wylie and Penelope McRedmond, (Basingstoke: Palgrave Macmillan, 2010): 41.

158 Ibid.

${ }^{159} \mathrm{Ibid}, 44$.
} 
dancers for entertainment, and often are also sexually abused. ${ }^{160}$ Young girls and women are also trafficked into sexual exploitation and are often traded to settle family feuds as brides. ${ }^{161}$ When those displaced in these conflicts are trafficked or smuggled to the British border, Davitti states that the UK fails to provide support regardless of the role that the state plays in the origin of their displacement. Davitti suggests that the short-term goals put in place by international groups are insufficient in tackling the trafficking problem, especially when vested economic interests are directly threatened.

Shelley explores the economic influence on trafficking and modern slavery, opening her argument by harkening back to the example of white slavery. Shelley states that the end of white slavery parallels the trafficking today. ${ }^{162}$ The Great Depression curbed demand for the sex industry and saw the tightening of international borders. The looming prospect of the Second World War and the US government's crackdown on organized crime meant that trafficking became increasingly difficult. When public outrage demanded government attention to the end of trafficking, the convergence was complete an international response ended white slavery. Again, relating to the concept that international cooperation can have an impact on combating these crimes. Today, economic downturns, global conflicts and social movements do effect trafficking. Global conflict and poverty displace populations, making them vulnerable to trafficking. As with the Great Depression, the 2008 economic downturn was seen to have a negative effect on some aspects of trafficking. Fewer people were able to afford sexual services and companies scaled back production and so the demand for forced labour waned briefly, but the bounce back was swift. It is clear that it will take more than economic constraints to end modern slavery and

\footnotetext{
${ }^{160}$ Ibid, 45.

${ }^{161}$ Ibid.

${ }^{162}$ Shelley, Human Trafficking: A Global Perspective, 296.
} 
human trafficking. Shelley argues there is no catch-all method capable of working in every country as the international nature of human trafficking is extremely complex. The concept of international cooperation can also be explored alongside international security.

Stewart Bell explores a security-based solution in Cold Terror: How Canada Nurtures and Exports Terrorism Around the World. Bell argues that Canada has been a traditional hotbed for nefarious organizations to raise money and fund international crime and violence. ${ }^{163}$ Bell argues that the Canadian system does a poor job of combating terror and crime. This failure is largely attributed to "leaky borders". In this light, Shelley also discusses the concept of leaky borders on a larger scale, stating that softer controls facilitate trafficking. ${ }^{164}$ Shelley identifies the Baltic borderlands as "porous" stating that Lithuania acts as a launching pad for traffickers into Germany, Scandinavia and the United States. ${ }^{165}$ The logical solution to porous borders would be the development of stronger borders with effectively trained guards and personnel, but this does not seem to discourage human trafficking. In "The Impact of Restrictive Immigration Policies on Human Trafficking in Canada”, Maja Muftic argues that increased security is, in fact, fueling the rise in the demand for human trafficking. ${ }^{166}$ As countries become harder to enter, criminal organizations see a higher demand for illegal passage. As a result, they are able to exploit migrants and charge even more money for passage. Muftic suggests that one option to combat trafficking in the Canadian context would be for the government to adopt "less strict immigration

\footnotetext{
${ }^{163}$ Stewart Bell, Cold terror: how Canada nurtures and exports terrorism around the world, (Mississauga: Wiley, 2005)

${ }^{164}$ Stoecker et al, Human traffic and transnational crime: Eurasian and American perspectives, 21. 165 Ibid.

${ }^{166}$ Maja Muftic, "The Impact of Restrictive Immigration Policies on Human Trafficking in Canada," University of Ottawa, no. MR61284 (2009) 94. Date accessed: March 10 ${ }^{\text {th }}, 2018$. https://search-proquestcom.ezproxy.lib.ryerson.ca/docview/520201637?pq-origsite=summon.
} 
policies." 167 According to Helton and Jacobs in "Combating Human Smuggling by Enlisting the Victims," making entry more difficult for migrants creates dependency and reliance on criminal organizations. Their article also discusses the concept of high securitization intimidating victims and causing them to keep quiet about their abusers. The primary objective should not be to inconvenience victims or make it harder for them to get into the country. The objective should be to go after organizations directly and work on alleviating the desperate state of the victims before they turn to trafficking or are trafficked. ${ }^{168}$ Although these arguments are convincing, they seemingly dismiss the importance of policing the criminal organizations involved in trafficking. These authors are able to demonstrate that traffickers prey on those who are unable to enter countries but suggesting that governments create more relaxed security policies as a means to alleviate this pressure is dangerous.

In "Children Trafficked to the United States," Elzbieta Gozdziak discusses the complexity of service provision and the trafficked child. Gozdziak conducted interviews with 140 children who were identified by the government in the United States as victims of human trafficking. Gozdziak argues that child victims of trafficking do not get the attention they deserve, stating that children are generally lumped into legal categories with women. ${ }^{169}$ This inherent connection to women only works to muddle statistics when investigating child trafficking. This is especially true when viewing statistics as they pertain to young girls. Attempts at prosecuting guilty parties are also hindered by this connection as laws vary

\footnotetext{
${ }^{167}$ Ibid, 97-98.

168 A. C. Helton \& E. Jacobs, "Combating human smuggling by enlisting the victims," Migration World Magazine 28, no. 4 (2000): 12-16.

${ }^{169}$ Elzbieta Gozdziak M, "Children Trafficked to the United States: Myths and Realities," Global Dialogue 14, (2012): 16.
} 
depending on the age of the victims. ${ }^{170}$ Gozdziak also draws attention to the fact that, although thousands of children are trafficked internationally per year by large crime syndicates, there are also a number of victims trafficked by their own families. ${ }^{171}$ In Gozdziak's interviews, the vast majority of the children had been trafficked by their own family into the United States. ${ }^{172}$ Many of the children did not feel as though they had been wronged by their families, creating an unexpected moral dilemma in the prosecution of perpetrators. Demonstrated here is the blurred line between trafficking and smuggling and the complexity surrounding primary research in trafficking. With concepts like the United States' T-Visa, which allows for trafficked people to stay in the US and apply for permanent residency after three years, desperation can drive families to commit these crimes. Although the T-Visa can be viewed as a step in the right direction, the concept of the blurred line and what people are willing to do in desperation lends itself to an argument around the forces that cause people to be trafficked.

Confusion also permeates the rehabilitation aspect of services for trafficked children. Gozdziak found that many of the children in her study did not wish to seek care on a social level, and were not interested in receiving psychiatric help. In one instance, a pair of 17-year-old boys who had been trafficked into a life of illegal forced labour did not wish to be emancipated, as they were paid small wages and allowed to send remittances home. ${ }^{173}$ Instead, the boys sought to exercise some agency over their lives as trafficked youth. Pearce, Hynes, and Bovarnick suggest that many child survivors tend to avoid psychiatric help because of the stigma surrounding it. ${ }^{174}$ Despite being plagued with emotional difficulties including missing family, feelings of isolation

\footnotetext{
${ }^{170}$ Ibid.

${ }^{171}$ Ibid, 20.

172 Ibid.

${ }^{173}$ Ibid, 21.

174 Jenny J. Pearce, Patricia Hynes and Silvie Borvarnick, Trafficked young people: Breaking the wall of silence, (London: Routledge, 2013): 37.
} 
and loneliness, disturbed sleep patterns, general anxiety, headaches, panic attacks, depression, and eating difficulties, trafficked children would consider post-traumatic stress issues as ailments of the heart rather than of the mind for worry of being associated with the stigma. ${ }^{175}$

The child demographic in human trafficking is remarkably complex and in turn, the services offered to these children must be fluid and adaptive. Gozdziak criticizes the lack of autonomy available to children present in services currently provided in the United States. Services that consider age as a key determinant in a child's ability to make informed decisions are essential. Specifying the parameters for the title of child or youth to include smaller age groups would also help to hone services. Gozdziak raises another issue in her article drawing attention to the fact that trafficked children come from all over the world. ${ }^{176}$ This international element to the victims of human trafficking is one of the main problems in providing care and rehabilitation services. Often, concepts of age and adolescence vary drastically depending on the country the child is born in. According to Gozdziak, the services provided in the United States tend to be oriented towards the reintroduction of trafficked children into the childhood that they missed while being trafficked and exploited. This concept of childhood is that of the western child. When attempting to reconstruct 'childhood', these services must consider the disparities between various cultures and religions. Language barriers and cultural customs create further confusion in the application of services for survivors of trafficking.

As discussed in "Human Trafficking and Migration Management in the Global South," Nawyn et al. explore the complexities of studying and combating trafficking. The authors argue that the international policies in place to combat trafficking may be harmful to victims, making

\footnotetext{
175 Ibid.

${ }^{176} \mathrm{Ibid}, 21$.
} 
them more vulnerable to traffickers. The authors state that the association of trafficking and modern slavery can be harmful, as the concept of modern slavery "frames human trafficking ineffectively as a problem to be solved best solved through law enforcement measures."177 Nawyn et al. suggest that rather than approaching human trafficking as a violent crime, it should be approached through a labour exploitation lens. In this context, exploitation can lead to several forms of violence, be it physical, mental or emotional. This argument relies on the fact that the association between modern slavery and trafficking automatically suggest physical violence is the paramount concern in trafficking and that mental and emotional violence are not considered. While understanding the various elements of trafficking is paramount in its study and prevention, but the association of modern slavery and trafficking can be beneficial. If defined correctly, modern slavery can not only provide a robust definition, but also attract attention that garners interest from an otherwise apathetic general public. Ignorance and apathy are crippling in today's society. As discussed by Kiril Sharapov in, "Productive Ignorance: Assessing Public Understanding of Human Trafficking in Ukraine, Hungary and Great Britain," ignorance and apathy are themes deeply present in the study of human trafficking. According to Sharapov, the lack of awareness and understanding of human trafficking has become a "socioeconomic and cultural quandary." ${ }^{178}$ Sharapov discusses the role of the government, and the manner in which neoliberalism and capitalism are ingrained in society. The policies favouring economic exploitation at play within modern society only feed demand for human trafficking and modern slavery. Without the interest of the general public in changing business practices and cognizance of the impact that wealthy countries have overseas, trafficking will persist.

\footnotetext{
${ }^{177}$ Stephanie J. Nawyn, Nur Banu Kavakli, Tuba Demirci-Yılmaz, and Vanja Pantic Oflazoğlu. "Human Trafficking and Migration Management in the Global South," International Journal of Sociology 46, No. 3 (2016): 190.

${ }^{178}$ Margaret Malloch, and Paul Rigby, Human Trafficking: The Complexities of Exploitation (Edinburgh: Edinburgh University Press, 2016) 17.
} 


\section{Conclusion}

In order to curb the trafficking of persons, a balance must be struck between stronger border controls and the alleviation of dependency in disparate areas of the world. Countries like Russia and China, whose governments are proven to suffer from corruption and aid in the trafficking of humans must be held accountable. The cooperation seen on the international stage means little if Russia and China are exempt. The case of Turkey demonstrates the potential for international cooperation in combatting trafficking. The arguments proposed by authors discussed above that explore more long-term approaches are extremely important. The trafficking of persons into failed states to work as soldiers, sex slaves, and labourers cannot be combatted with border security and international cooperation against corruption and organized crime. In these cases, understanding the impact of international business practices in producing global poverty and the role that developed nations play in perpetuating conflict must be addressed. Calling for a fundamental shift in how nations approach global production and the sustainability of the global economy is a lofty and abstract plan but needs to be understood as vital in combatting trafficking.

Human trafficking today is often understood and studied as a by-product of conflict and economic disparities. Although this is true to a certain extent, understanding trafficking in this way reduces it to a problem that can only be solved by the near impossible eradication of global conflict and poverty. Human trafficking needs to be addressed directly as a means to mitigate the "big picture" issues, like poverty and conflict not as an issue solved by the eradication of these 
problems. Louise Shelley aptly states that viewing trafficking as a by-product “...has resulted in a response that is not commensurate with the scale or the rapid growth of human trafficking." 179

Above all, the simplest and least demanding method to combat trafficking and modern slavery is education. Educating the consumers fueling the demand for cheap goods needs to be more prevalent globally. Understanding the impact that international production has on poorer populations is vital in combating the ignorance and apathy that cripples efforts for ending trafficking and modern slavery. Today's environment renders human trafficking as an opportunity for illegitimate criminal organizations to gain power and profit by supplying organizations considered 'legitimate' with cheap goods and services. Slavery is alive and well today, it did not end and is sustained by global demand for cheap labour and systemic corruption, understanding this is paramount in ending trafficking and modern slavery.

${ }^{179}$ Shelley, Human Trafficking: A Global Perspective, 39. 


\section{$\underline{\text { References }}$}

Amin-Khan, Tariq. "Security and its impact on migrants and refugees." In Immigrant Experiences in North America: Understanding Settlement and Integration. Ed. Harald Bauder and John Shields, 118142. Toronto: Canadian Scholars’ Press, 2015.

Bales, Kevin. Blood and Earth: Modern Slavery, Ecocide, and the Secret to Saving the World. New York: Spiegel \& Grau, 2016.

Bales, Kevin. Disposable People: New Slavery in the Global Economy. California: University of California Press, 1999.

Bales, Kevin. "What predicts human trafficking?" International Journal of Comparative and Applied Criminal Justice 31. No 2 (2007): 269-79.

Bales, Kevin, Zoe Trodd and Alex Kent Williamson. Modern Slavery: A Beginners Guide. Oxford: Oneworld Publications, 2009.

Beaumont, Hilary. "Three Years After a Factory Collapse Killed 1,130 Workers, This Brand is Still Making Clothes in Bangladesh." Vice News. April 22, 2016. Date accessed March 20 2018. https://news.vice.com/article/three-years-after-a-factory-collapse-killed-1130-workers-this-brand-is-stillmaking-clothes-in-bangladesh.

Bell, Stewart. Cold terror: how Canada nurtures and exports terrorism around the world. Mississauga: Wiley, 2005.

Bravo, Karen E. "Free Labor! A Labor Liberalization Solution to Modern Trafficking in Humans." Transnational Law \& Contemporary Problems 18, no. 3 (2009):

Burke, Mary C. Human Trafficking: Interdisciplinary Perspectives. London: Routledge, 2013.

Cengiz, Mahmut. "The Globalisation of Turkish Organized Crime and the Policy Response." ProQuest Dissertations Publishing, 2010.

Cheloukhine, Serguei. "The Roots of Russian Organized Crime: From Old-Fashioned Professionals to the Organized Criminal Groups of Today." Crime, Law and Social Change 50, no. 4 (2008): 353-374.

Davitti, Daria. "Shirking Responsibilities: Receiving Countries and the Structural Causes of ConflictRelated Child Trafficking." In Human Trafficking in Europe, ed. Gillian Wylie and Penelope McRedmond, 41-59. Basingstoke: Palgrave Macmillan, 2010.

Doezema, Jo. "Loose Women Or Lost Women? the Re-Emergence of the Myth of White Slavery in Contemporary Discourses of Trafficking in Women." Gender Issues 18, no. 1 (1999)

Fraser, Sarah. "Human Trafficking in the Democratic Republic of Congo." Borgen Magazine. November 21, 2017. Date accessed: June $20^{\text {th }}, 2018$. http://www.borgenmagazine.com/human-trafficking-

democratic-republic-congo/. 
"Global estimates of modern slavery: Forced labour and forced marriage." International Labour Office (ILO). United Nations. Geneva, 2017. , date accessed: August $1^{\text {st }}, 2018$, https://www.ilo.org/global/publications/books/WCMS_575479/lang--en/index.htm.

“Global Slavery Facts.” Free the Slaves. Last modified, 2018. Date Accessed: July 15 ${ }^{\text {th }}, 2018$. https://www.freetheslaves.net/.

Gozdziak, Elzbieta M. "Children Trafficked to the United States: Myths and Realities." Global Dialogue 14, (2012): 51-61.

Gozdziak, Elzbieta M. and Elizabeth A. Collett. "Research on Human Trafficking in North America: A Review of Literature." International Migration 43, no. 1-2 (2005).

Helton, A. C. \& Jacobs, E. "Combating human smuggling by enlisting the victims." Migration World Magazine 28, no. 4 (2000) 12-16.

"Human Trafficking: More than 20 million victims." European Parliament. last modified October 18, 2016. http://www.europarl.europa.eu/news/en/headlines/world/20161014STO47261/human-traffickingmore-than-20-million-victims-worldwide.

“Human Trafficking and United Nations Peacekeeping.” DPKO Policy Paper. (2004).

Jennings, Kathleen and Vesna Nikolic-Ristanovic. "UN Peacekeeping Economies and Local Sex Industries: Connections and Implications." MICROCON Reseach Working Paper. No. 17 (2009)

Krikorian, Mark. "Mass Immigration Defeats Homeland Security." In Immigration Policy and the Terrorist Threat in Canada and the United States, ed. Martin Collacott and Alexander A. Moens, 37-52. Vancouver: Fraser Institute, 2008.

Lutsenko, Yevhenia, Lydia Matiaszek, Shivaum Scanlan, Inna Shvab. "Trafficking in Ukraine: An Assessment of Current Responses.” UNICEF. Kyiv: UNICEF, 2005.

Malloch, Margaret, and Rigby, Paul. Human Trafficking: The Complexities of Exploitation. Edinburgh: Edinburgh University Press, 2016.

McQuigge, Michelle. "Airbnb rentals being used for alleged human trafficking: Toronto police." Global News. February 22, 2018. Date accessed: August $10^{\text {th }}, 2018$. https://globalnews.ca/news/4041603/airbnbhuman-trafficking-toronto/.

Mendelson, Sarah E. Barracks and Brothels: Peacekeepers and Human Trafficking in the Balkans. Washington: Center for Strategic \& International Studies, 2005.

Millar, Hayli, Tamara O'Doherty, and Katrin Roots. "A Formidable Task: Reflections on Obtaining Legal Empirical Evidence on Human Trafficking in Canada." Anti-Trafficking Review no. 8 (2017).

Muftic, Maja. "The Impact of Restrictive Immigration Policies on Human Trafficking in Canada." University of Ottawa. no. MR61284 (2009) 1-115. Date accessed: March, 10 $0^{\text {th }} 2018$. https://searchproquest-com.ezproxy.lib.ryerson.ca/docview/520201637?pq-origsite=summon. 
Munck, Ronaldo. "Slavery: Exception or Rule?" in Human Trafficking in Europe, ed. Gillian Wylie and Penelope McRedmond, 17-29. Basingstoke: Palgrave Macmillan, 2010.

Nawyn, Stephanie J., Nur Banu Kavakli, Tuba Demirci-Yılmaz, and Vanja Pantic Oflazoğlu. "Human Trafficking and Migration Management in the Global South." International Journal of Sociology 46. No. 3 (2016): 189-204.

Newman, Brook E. "Historical Perspective: Slavery Over the Centuries." in Human Trafficking: Interdisciplinary Perspectives, ed. Mary C. Burke, 24-47. New York: Routledge, 2013.

Ōkubo, Shirō and Louise I. Shelley. Human Security, Transnational Crime and Human Trafficking: Asian and Western Perspectives 6. London: Routledge, 2011.

Oxman- Martinez, Jacqueline \& Hanley, Jill. “A Follow-up Study of Canadian Policy on Human Trafficking: Impacts of the Immigration and Refugee Protection Act." Montreal: McGill University, 2004.

Petley, Christer. "Slaveholders and revolution: the Jamaican planter class, British imperial politics, and the ending of the slave trade, 1775-1807." Slavery \& Abolition 39. No. 1 (2017): 53-79.

Pearce, Jenny J, Patricia Hynes and Silvie Borvarnick. Trafficked young people: Breaking the wall of silence. London: Routledge, 2013.

Russell, Cynthia L. "An Overview of the Integrative Research Review." Progress in Transplantation 15, no. 1 (2005).

"Risk Averse? Company reporting on raw material and sector-specific risks under the Transparency in Supply Chains clause in the UK Modern Slavery Act 2015." CORE. (2017).

http://corporatejustice.org/171003_risk-averse-final-1.pdf

Shelley, Louise I. Human Trafficking: A Global Perspective. Cambridge: Cambridge University Press, 2010.

Smith, R. Scott \& Christopher Francese. Ancient Rome: An Anthology of Sources. Indianapolis: Hackett Publishing Company, 2014.

Snell, Daniel C. "Slavery in the Ancient Near East" in The Cambridge World History of Slavery. Volume 1: The Ancient Mediterranean World, ed. Elizabeth Meyer, 4-22. The Classical Journal 180, no. 2 (2012)

Sokolov, Vsevolod. "From Guns to Briefcases: The Evolution of Russian Organized Crime." World Policy Journal 21, no. 1 (2004): 68-74.

Stephens, Amy, Romesh Hettarachchi and Sung Hyun Yun. "Responding to labour trafficking, Suggestions for experiences of local service providers." In Labour Migration, Human Trafficking and Multinational Corporations: The Commodification of Illicit Flows. Ed. Ato Quayson and Antonela Arhin, 152-158. London: Routledge, 2012.

Stoecker, Sally W. and Louise I. Shelley. Human traffic and transnational crime: Eurasian and American perspectives. Lanham: Rowman \& Littlefield, 2005. 
“Temporary Resident Permits (TRPs)" Government of Canada, date modified, August 1 ${ }^{\text {st }}, 2015$, date accessed: August 13 ${ }^{\text {th }}, 2018$. https://www.canada.ca/en/immigration-refugees-

citizenship/corporate/publications-manuals/operational-bulletins-manuals/temporary-

residents/permits/when-to-consider-issuing.html.

"The Harper Government Launches Canada's National Action Plan to Combat Human Trafficking." Public Safety Canada. Last modified, June $6^{\text {th }}, 2012$.

https://web.archive.org/web/20130703001948/https://www.publicsafety.gc.ca/media/nr/2012/nr20120606 -eng.aspx

United Nations. "Convention on the Rights of the Child.” Treaty Series 1577. 1989.

UN General Assembly. "Convention against Transnational Organized Crime.” November 2, 2001 (New York: United Nations Publications)

UNODC. "Global Report on Trafficking in Persons 2016" (United Nations publication, Sales No. E.16.IV.6).

United Nations. "Protocol Against the Smuggling of Migrants by Land, Sea and Air, Supplementing the United Nations Convention Against Transnational Organized Crime," UNCJN, 2000.

United Nations. "Protocol to Prevent, Suppress and Punish Trafficking in Persons, especially Women and Children, Supplementing the United Nations Convention Against Transitional Organized Crime."

UNCJN, 2000.

US Department of State. Trafficking in Persons Report. June 2017.

https://www.state.gov/documents/organization/271339.pdf

"What is forced labour?" anti-slavery. Last modified, 2018. Date accessed: July 15 $5^{\text {th }}, 2018$.

https://www.antislavery.org/slavery-today/forced-labour/.

"What is human trafficking?" anti-slavery. Last modified, 2018. July 15 2018.

https://www.antislavery.org/slavery-today/human-trafficking/.

"What is modern slavery?" anti-slavery. Last modified, 2018. July 15 $5^{\text {th }}, 2018$.

https://www.antislavery.org/slavery-today/modern-slavery/.

Withrow, Brian L. Research Methods in Crime and Justice. London: Routledge, 2013.

"Woman, 2 men charged in Toronto human trafficking case." Global News. May 16, 2018. Date accessed: May 25, 2018. https://globalnews.ca/news/4212567/3-charged-toronto-human-trafficking-case/

Younes, Ali. "A tale of human traffickers and Libyan slave markets." Mail \& Guardian. November 29, 2017. https://mg.co.za/article/2017-11-29-a-tale-of-human-traffickers-and-libyan-slave-markets.

Zhang, Sheldon X. \& Ko-Lin Chin. "Snakeheads, mules, and protective umbrellas: a review of current research on Chinese organized crime." Crime Law Social Change 50. (2008): 177-195.

Zhang, Sheldon and Ko-Lin Chin. "Enter the Dragon: Inside Chinese Human Smuggling Organizations." Criminology 40, no. 4 (2002): 737-768. 